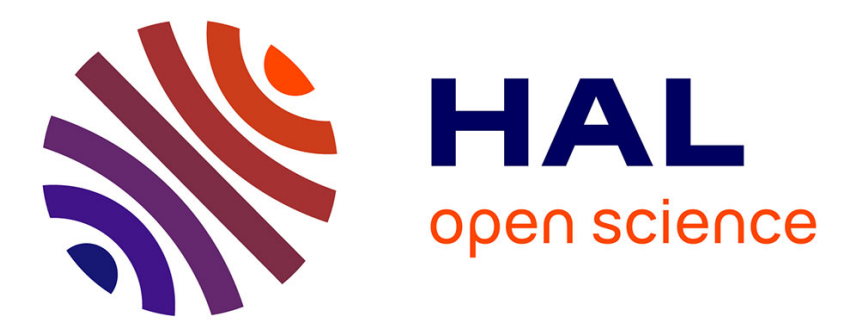

\title{
Possible polyphase periglaciation and glaciation adjacent to the Moreux impact-crater, Mars
}

R. J. Soare, S.J. Conway, J.-P. Williams, A. J. Hepburn

\section{To cite this version:}

R. J. Soare, S.J. Conway, J.-P. Williams, A. J. Hepburn. Possible polyphase periglaciation and glaciation adjacent to the Moreux impact-crater, Mars. Icarus, 2021, 362, pp.114401. 10.1016/j.icarus.2021.114401 . hal-03186645

\section{HAL Id: hal-03186645 https://hal.science/hal-03186645}

Submitted on 31 Mar 2021

HAL is a multi-disciplinary open access archive for the deposit and dissemination of scientific research documents, whether they are published or not. The documents may come from teaching and research institutions in France or abroad, or from public or private research centers.
L'archive ouverte pluridisciplinaire HAL, est destinée au dépôt et à la diffusion de documents scientifiques de niveau recherche, publiés ou non, émanant des établissements d'enseignement et de recherche français ou étrangers, des laboratoires publics ou privés. 
1

2

6

\section{Possible polyphase periglaciation and glaciation}

adjacent to the

Moreux impact-crater, Mars

R.J. Soare, ${ }^{1}$ S.J. Conway, ${ }^{2}$ J-P Williams,${ }^{3}$ A.J. Hepburn ${ }^{4}$

${ }^{1}$ Geography Department, Dawson College, Montreal, Qc, Canada, H3Z 1A4 (rsoare@dawsoncollege.qc.ca)

${ }^{2}$ UMR, CNRS 6112, 2 rue de la Houssinière, 44322, Nantes, Cedex 3, France

${ }^{3}$ Earth, Planetary and Space Sciences, University of California, Los Angeles, CA, USA

${ }^{4}$ Department of Geography and Earth Sciences, Aberystwyth University, Aberystwyth, UK

Pages: 50

Figures: 20

Keywords: Mars, atmosphere, climate, surface 


\section{Abstract}

The cyclicity and temporal succession of glacial-periglacial periods or epochs are keynotes

of cold-climate geology on Earth. Relatively recent work within the Mars community has begun to dissect the mid- to higher-latitudinal terrain of Mars for analogical evidence of similar coldclimate cyclicity and succession.

Here, we carry on with this work by focusing on the terrain immediately to the north of the Moreux impact-crater $\left(40-44^{0} \mathrm{~N}, 43-47^{0} \mathrm{E}\right)$. The crater is located in northern Arabia Terra, to the south of Protonilus Mensae. It lies astride of and postdates Mars' crustal-dichotomy. The latter is a global geological-boundary that separates the ancient southern-highlands from the relatively younger northern-lowland plains.

Using cross-cutting relationships, relative stratigraphy and crater-size frequency distributions $(C S F D s)$ we identify three glacial and two periglacial periods that are temporally intertwined and differentiated by a suite of features unique to each of these periods. For example, we report and discuss clusters of pingo-like mounds amidst ridge and trough terrain or "brain terrain". On Earth, the former are the work of freeze-thaw cycling; on Mars, the latter are thought to be glacial remnants. In turn, the brain terrain is underlain by small-sized polygons possibly formed by thermal contraction cracking and with margins underlain by degraded ice-wedges. Age estimates derived of CSFDs suggest that the polygonised terrain could as much as $\sim 100 \mathrm{Ma}$, whereas the brain terrain and pingo-like mounds are thought to be $\sim 1-\sim 10 \mathrm{Ma}$. Possible terminalmoraines that intercept brain-terrain fragments point to an even more recent period of glaciation If the CSFD age-estimates are valid, then the polygons that underlie the brain terrain and incise the basin floors of our study zone could be an order of magnitude older than most of the age estimates associated with polygonised terrain at other locations on Mars. The fact that there are 
52 two distinct periods of polygonization and periglacial activity with a wide offset of time within

53 one relatively small study zone also highlights the extent to which the freeze-thaw cycling of water

54 might be rooted as iteratively and as deeply in Mars' geological history as is its glaciation.

\section{1. Introduction}

Our study zone is immediately to the north of the Moreux impact-crater $\left(40-44^{0} \mathrm{~N}, 43-47^{0}\right.$

57 E) in northern Arabia Terra (Fig. 1). The latter lies astride of and postdates Mars' crustaldichotomy, a global geological-boundary that separates the ancient southern highlands (McGill and Dimitriou, 1990; Frey et al., 2002) from the relatively younger northern lowlands (Head et al., 60 2002; Tanaka et al, 2005).

Here, as elsewhere at similar and higher latitudes within both hemispheres, landscape

62 assemblages, landforms and surface textures pointing to the work of: glaciation, i.e. the net and 63 perennial accumulation (aggradation) or degradation of atmospherically-precipitated (water) ice; 64 and, periglaciation, i.e. environments dominated by frost action and often, but not necessarily, the 65 freeze-thaw cycling of water.

The long-term cyclicity and temporal succession of glacial-periglacial periods or epochs

67 are keynotes of cold-climate geology on Earth. Relatively recent work within the Mars community

68 has begun to dissect the mid- to higher-latitudinal terrain of Mars for analogical evidence of similar 69 cold-climate cyclicity and succession (e.g. Dickson et al., 2008; Levy et al., 2009; Baker et al., 70 2015; Hubbard et al., 2011; Souness and Hubbard, 2013; Sinha and Murty, 2015; Hepburn et al., 71 2020).

72 Below, we carry on with and extend the range of this work to our study zone. In so doing 73 we have three principal aims: 

87 therein.

\section{Methods}

Two HiRISE images (High Resolution Imaging Science Experiment, Mars Reconnaissance Orbiter, MRO, McEwen et al., 2007) (ESP_045349_2235, 43.405 ${ }^{0} \mathrm{~N} ; 44.108^{0} \mathrm{E}$; and, ESP_042105_2235, $43.163^{0} \mathrm{~N} ; 43.983^{\circ} \mathrm{E}$ ) and one CTX image (Context Camera, Malin et al., 2007) (J01_045349_2239_XN_43N316W，43.940 N; 43.990 E) frame our study region geographically and were used to evaluate cross-cutting relationships and relative stratigraphy compared with modeled crater-retention age isochrons from Hartmann (2005) using Craterstats 2

91 (Michael and Neukum, 2010; Michael et al., 2016).

1) Integrate cross-cutting relationships and relative stratigraphy to posit a possible geochronological ordering of the disparate glacial and periglacial assemblages, landforms and surface textures.

2) Use crater-size frequency distribution to frame the proposed geochronological ordering in absolute terms.

3) Estimate the temporal distance between the latest and earliest onset of glaciation or periglaciation.

Crater counts were conducted using the Cratertools plug-in for the ERSI ArcGIS to measure crater diameters (Kneissl et al., 2011). Crater size-frequency distributions (CSFDs) were

\section{Observations}

Small-sized ( 5-15 $\mathrm{m}$ in diameter) and clastically non-sorted polygons (Type-1) are ubiquitous in their coverage of the two basins in our study region (Fig. 2a-c). They also incise some of the terrain near the eastern margin of the northernmost basin and are observed upslope as well on its flanks (Figs. 2a, c). The polygons are shaped irregularly. Some of the polygons show 
97 centres elevated slightly above the polygon margins, or high-centred polygons [HCPs]. Polygon 98 margins are metres to sub-metres in width and may or may not comprise sub-metre deep troughs A slightly larger and morphologically-different type of polygon (Type-2) also is observed

100 101 102 103 104 105 106 107 108 109 110 111 112 113 within the basins (Figs. 3a-b). The polygons tend to be four-sided, not irregular or asymmetrical, show margins that are etched slightly deeper and wider than the basin-surface polygons, and are sub-divided by secondary cracks. Some of the polygons centres are knobby; many of them are relatively flat. Mirroring the spatially-constrained distribution of the basin-surface polygons, none of the etched polygons are observed beyond the basin borders.

The etched polygons occur amidst terrain superposed on the polygonised basin-surface. The terrain, in turn, comprises outcrops, ridges and troughs, and small-sized mounds, described below, each of which may or may not be contiguous. Outliers, distal from the principal areas of distribution, are commonplace.

One of the basins in our study region exhibits wave-like and (mostly) equator-facing scarps that span its multiple-kilometer reach (Fig. 4). The scarps display metres to decametres of horizontal separation and, individually, metres of vertical drop. On a smaller scale the polygonised surface-basins also show uneven topography. The latter comprises metres-scale, serialized and sub-parallel undulations (Figs. 5a-b). The undulations are shallow, perhaps comprising a few metres of depth, exhibit kilometres ${ }^{2}$ of reach and display a NE/SW vector; their minor axes are scaled to the diameter of individual polygons. Elsewhere, circular to sub-circular and rimless depressions are distributed in two basin-wide arcs (Fig. 5c). The depressions seemingly scale to the same shallow depth as the undulations noted above.

Coverage of the polygonised basins and overprinting by ridge and trough structures and assemblages is widespread (Figs. 6, 7a). Individual ridges and troughs are metres in elevation and 
120

121

122

123

124

125

126

127

128

129

130

131

132

133

134

135

136

137

138

139

140

141

142

metres to decametres in width (Fig. 7c). Some of the ridge-trough assemblages are open; others are closed (Fig. 7c). Long axes often trend longitudinally (Fig. 7c). Numerous basins show a gradual decrease in the mass, height and surface coverage of the ridges and troughs as they edge further into the basin midsts and away from the margins (Figs. 7a-b), also Fig. 6). Spatial outliers also are observed throughout the basin surfaces (Fig. 7b).

As noted above, etched mounds populate the terrain superposed on the polygonised basinsurfaces. (Figs. 3a-b, 8a-d). Typically, long axes are sub-kilometre, elevation is scaled in metres, and shape is circular to sub-circular. Numerous mounds exhibit morphological asymmetry or irregularities at and within their margins, possibly by way or erosion or ablation (Figs. 8a-c). Many but not all of the mounds are clustered and contiguous with the larger-scale distributions of etched terrain on the polygonised basins (Fig. 8b). No mounds or mound remnants are observed on the elevated terrain that flank the basins.

The eastern flank (HiRISE image ESP_045349_2235) shows multiple closely-set and bowshaped ridges (Fig. 9). The long-axial distribution of these ridges roughly follows the long axis of the polygonised basin and exhibits kilometres of reach (Fig. 9). Most of the ridges comprise decametre to metre-scale boulders distributed continuously or discontinuously (Fig. 10a). At one location, as many as nine serialised ridges are observed (Fig. 10a). Some of the ridges are subtle, being largely absent of boulders and observable only by means of a gentle decametres-wide and metres-high change of (basin-surface) elevation (Fig. 10a). A much denser distribution of boulders is observed at the topographical transition between the basin surface and the rockier flankingterrain immediately to the east (Figs. 10a-b). Where the ridges intercept the ridge-trough terrain the amplitude and mass of the former increases perceptibly, compared to the ridge segments where no interception occurs (Fig. 11). 
Parallel albeit discontinuous lineations normal to these ridges intercept the latter and extend beyond them infrequently (Figs. 10b-c). The lineations show a strong variance in length, from multiple to hundreds of metres, and incise the same type of polygonised terrain that covers the basin surface elsewhere (Fig. 10d). Some of the lineations comprise metre-wide grooves with metre-to decametre-scale boulders nested therein; boulder size, most often, appears to vary randomly (Fig. 10c); others, comprise surface boulders whose size also seems to vary randomly. A few lineations exhibit smaller boulders on the lee side of larger ones (Fig. 10c).

Two other items are of note. First, much like the distribution of the serialized ridges, the density of boulder alignments and grooves increase with proximity to the basin's edge and the rockier terrain adjacent to the edge (Figs. 10a-c). Second, at some locations the grooved surfacelineations at/near basin edges extend through the positively sloped basin-adjacent terrain (Fig. 9, top right-hand corner).

\section{Periglacial landscapes on Earth}

\subsection{Thermal-contraction polygons}

Small-sized polygons are commonplace features of permafrost landscapes on Earth (e.g. Lachenbruch, 1962; Mackay, 1974; 1999; Czudek and Demek 1970; Washburn, 1973; Rampton and Bouchard 1975; Rampton, 1988; French, 2007) (Figs. 12a-b). Typically $\leq 25 \mathrm{~m}$ in diameter, the polygons are produced by the tensile-induced fracturing of frozen sediment. This occurs when the latter undergoes a sharp drop of sub-zero (Celsius) temperatures (de Leffingwell, 1915; Lachenbruch, 1962). Fracturing, or thermal-contraction cracking, opens up shallow, narrow and vertical veins (Lachenbruch, 1962). In-filling prevents the ground from relaxing and returning to its pre-cracked state as temperatures rise. Subsequent cycles of cracking and relaxation increase the depth and the width of the veins, eventually forming wedges. 
The fill type depends on the ambient boundary-conditions and the availability of: 1)

167

168

169

170

171

172

173

174

175

176

177

178

179

180

181

182

183

184

185

186

187

188 meltwater derived of thawed snow or ice; 2) winter hoarfrost; or, 3) windblown sand, mineral-soil, or a mixture of the two (e.g. de Leffingwell 1915; Péwé 1959; Lachenbruch 1962; Washburn 1973; Sletten et al. 2003; Hallet et al. 2011) (Figs. 12b-d). The diurnal and seasonal iteration of cracking and filling grows the sub- to centimetre-scale veins into wedges with metre-scale depth and width (Lachenbruch, 1962). As the cracks intercept one another they form individual polygons and, eventually, consolidated polygon networks (Figs. 12a-b). The latter may comprise hundreds of square kilometres of continuous or discontinuous coverage and represent hundreds of cycles (e.g. Black 1954; Lachenbruch 1962; Washburn 1973; Mackay 1974).

As ice- and/or sand-wedges aggrade by means of seasonal/annual supplements of fill, the wedges and their sedimentary overburdens may rise above the elevation of the polygon centres; this forms low-centred polygons [LCPs] (Péwé, 1959; Washburn 1973; Harris et al., 1988; Rampton, 1988; French, 2007). Ice or sand-wedge degradation, by thaw in the case of the former, or aeolian erosion in the case of the latter, degrades and depletes wedge mass. If and as the wedges fall below the elevation of the polygon centres the polygons begin to show high-centres $[H C P s]$ (Péwé, 1959; Washburn 1973; Harris et al., 1988; Rampton, 1988; French 2007) (Fig. 12a). Some ice/sand-wedge polygons show neither elevated nor collapsed margins. This is indicative of morphological nascency, evolved insufficiently to uplift marginal overburdens, or of a transitional and topographically-neutral stage between aggradation and degradation.

Ice and sand-wedge polygons show a similar range of morphologies, depending on their stage of aggradation, degradation or neutrality. However, the respective presence or absence of sand-wedge polygons within a permafrost landscape points to climatic, hydrological and aeolian regimes that differ markedly from the regimes associated with ice-wedge polygons. Although the 
189 terrain fractured by sand-wedge polygons does require some ice-cementation (Lachenbruch, 190 1962), the boundary conditions associated with these polygons tend to be arid and extremely cold 191 (Péwé, 1959; Lachenbruch, 1962; French and Guglielmin, 2000; Murton et al., 2000; Marchant et 192 al., 2002; Sletten et al., 2003; Hallet et al. 2011; Wolfe et al., 2018). Permafrost landscapes where 193 surface water is bountiful and freeze-thaw cycling is commonplace exhibit greater populations of 194 ice-wedge than sand-wedge polygons (Péwé, 1959; Lachenbruch, 1962; French and Guglielmin, 195 2000; Murton et al., 2000; Sletten et al., 2003; Hallet et al. 2011; Wolfe et al., 2018).

The vulnerability of ice-wedge polygons to thaw means that the concurrent observation of

197 low- and high-centred ice wedge polygons, or even a landscape dominated by high-centred 198 polygons and thaw pits, would be expected when ice-rich landscapes undergo thermal stress and 199 disequilibrium (Péwé, 1959; Washburn 1973; Harris et al., 1988; Rampton, 1988; French, 2007; 200 Farquharson et al., 2019). degradation are based uniquely on a gain of mass by aeolian deposition or mass loss by aeolian erosion. As aeolian processes would not be expected to vary substantially on a highly-localised 204 scale, the closely set presence of low- and high-centred sand-wedge polygons in a permafrost 205 landscape would be unusual (e.g. Péwé, 1959; French and Guglielmin, 2000; Marchant et al., 2002;

206 Sletten et al., 2003; Hallett et al., 2011).

2074.2 Thermokarst and ice-rich permafrost

Thermokarst refers to terrain in permafrost regions of excess ice which, depending upon 209 the currency of warming or cooling trends, could undergo frost heave or settlement as the excess 210 ice aggrades or degrades in situ (Taber, 1930; Penner, 1959; Hussey, 1966; Hughes, 1974; 211 Rampton, 1988) (Fig. 12d). Excess ice equals the volume of ice in the ground that exceeds the 
212 total pore-volume that the ground would have under natural unfrozen conditions (Harris et al., 213 1988; also, see Taber, 1930; Penner, 1959; Rampton and Mackay, 1971; Washburn, 1973;

214 Rampton, 1988; French, 2007).

215 Excess ice may comprise lenses, veins or larger masses of consolidated ice such as tabular 216 ice. All of these ice types originate and develop by the work of ice segregation. Ice segregation, 217 in turn, is the result of cryosuction pulling pore water to a freezing front where the ice consolidates 218 into lenses and, over time, into more substantial bodies of ice (e.g Taber, 1930; Black, 1954; 219 Penner, 1959; Rampton and Mackay, 1971; Rampton, 1988; French, 2007). As this occurs, the 220 overlying terrain undergoes frost heave proportional to the volumetric growth of ice-segregated 221 lenses; frost settlement occurs when these lenses thaw or degrade and the newly voided or de-iced 222 soil settles under its own weight (e.g. Harris et al., 1988; Osterkamp et al., 2009; Farquharson et 223 al., 2019).

224 Fine to medium-grained soils such as silts or silty clays are particularly adept at hosting 225 segregation ice because they have relatively-small interstices (e.g. Taber, 1930; Black, 1954; 226 Penner, 1959; Rampton and Mackay, 1971; Rampton, 1988; French, 2007). Were the grain-size 227 too fine, the migration of pore-water to the freezing front would be overly constricted and 228 inadequate to the requirements of segregation-ice formation; opposingly, were the grain-size too 229 coarse, the migration of pore-water would be overly expeditious and flush out of the system before 230 segregation ice could form.

The oscillation of regional mean-temperatures is one of the principal drivers of frost heave 232 and settlement (e.g. Péwe, 1954; Czudek and Demek, 1970; Murton, 2001; Grosse et al., 2007; 233 Osterkamp et al., 2009; Schirrmeister et al., 2013; Wetterich et al., 2014). This is exemplified, in 234 part, by the hummocky sediments and rolling topography of the Tuktoyaktuk Coastlands of 
235 northern Canada (e.g. Rampton and Mackay, 1971; Rampton, 1988; Murton, 2001) and

236 northeastern Siberia (e.g. Czudek and Demek, 1970; Grosse et al., 2007; Schirrmeister et al., 237 2013).

238 The time-frame of excess-ice aggradation and degradation, or of ice-induced heave and 239 settlement, however, need not be synchronous (e.g. Rampton and Mackay, 1971; Rampton, 1988; 240 Farquharson et al., 2019). For example, the wide-ranging presence of thermokarst lakes and alases 241 (thermokarst-lake basins absent of water) throughout the Tuktoyaktuk Coastlands is rooted in the 242 relatively recent Holocene Era (e.g. Rampton and Mackay, 1971, Rampton 1988;). Contrarily, the 243 radiocarbon dating of wood ensconced in segregation-ice lenses and beds that are metres to tens 244 of metres deep point to region-wide ice-enrichment having taken place thousands and possibly 245 tens of thousands of years ago during the middle to late Wisconsinian glacial stade (Rampton and 246 Bouchard, 1988). This means that the geochronological distance or offset of time between ice 247 enrichment and depletion can be substantial.

2484.3 Perennially ice-cored mounds

Cold-climate and non-glacial landscapes on Earth show disparate mound types, i.e. earth 250 hummocks (e.g. Pettapiece, 1974; Kokelj et al., 2007), frost blisters (e.g. van Everdingen, 1982; 251 Pollard and French, 1985), and pingos, hydrostatic (e.g. Mackay, 1998) or hydraulic (e.g. Müller, 252 1963). Of these four types, only the pingos scale to the height and width of the mounds in our 253 study region and are perennial.

254 4.3.1 Closed-system pingos

255 Hydrostatic, or closed-system, pingos [CSPs] are uniquely tied to ice-rich periglacial 256 landscapes (e.g. Müller, 1963; Washburn, 1973; Mackay, 1998; French, 2007). They originate and 257 develop in response to the loss of thermokarst lake-water by drainage or evaporation (Figs. 13a- 
258

259

260

261

262

263

264

265

266

267

268

269

270

271

272

273

274

275

276

277

278

279

280 d). Lake-water loss triggers the propagation of a freezing front from the newly-exposed basin sides or floor. Pore water undergoes expulsion ahead of the freezing front into an increasingly compressed area of unfrozen ground, usually at or near the topographical low(s) of the basin. As the hydrostatic pressure of the expelled pore-water increases, the basin floor begins to deform and uplift. This creates a dome-like structure or mound. If and when the underlying water freezes, an ice core forms (Mackay, 1998, 1999) (Fig. 13b).

Mound shape, usually circular to sub-circular, is determined by the morphology or bathymetry of the lake basins in which the mound is nested (e.g. Washburn, 1973; Mackay, 1998, 1999; French, 2007). Mound height (metres to decametres) and long-axis diameters (metres to hundreds of metres) are a function of four variables: 1) the surface area of the basin; 2) the volume of pore water surrounding the basin that is exposed to permafrost aggradation; 3) the stage of development, i.e. nascent, adolescent or growing, and mature or stagnant; and, 4) current (freezingfront) boundary conditions remaining relatively constant (Mackay 1998). Were thaw temperatures to be lost from this cycling, arresting the loss of lake water and the further exposure of the thermokarst lake-basin pore water, the shape, size and height of the pingo would be fixed. OSPS are less sensitive to this type of temperature-based fixation. Neither the migration of topographically-driven or of deeply seated/geothermal water to the site of mound formation is contingent upon freeze-thaw boundary conditions at/or near the surface.

Metres-wide and deep fissures - dilation cracks - are not unusual amongst larger closedsystem pingos (Fig. 13c). These cracks propagate and trend from the mound summit as the pingo grows and tensile stresses increase (e.g. Washburn, 1973; Mackay, 1998, 1999; French, 2007). Mirroring the degradational pathway of the OSPS (see the discussion below), the summit cracks of CSPs may evolve into depressions as the thermal integrity of the overburden and the underlying 
281 ice-core dissipates (Fig. 13c). Subsequent stages of mound degradation possibly comprise fans,

282 slumps and collapse, leaving slightly elevated and irregular ramparts encircling the collapse basin

283 in the wake (Fig. 13d).

284 4.3.2 Open-system pingos

285

Hydraulic or open-system pingos [OSPs] are circular to sub-circular in some instances (e.g.

286 Bennike, 1983; Worsley and Gurney, 1996; Scholz and Baumann, 1997; Kelly, 2001) and linear,

287 oblong or irregular in others (Cruickshank and Calhoun, 1965; O’Brien, 1971; Worsley and

288 Gurney, 1996; Kelly, 2001). Mound height ranges from metres to decametres and long axes may

289 reach hundreds of metres (Cruickshank and Colhoun, 1965; Allen, 1976; Bennike, 1983; Sholz

290 and Baumann, 1997; Kelly, 2001) (Figs. 14a-d).

291 Fractures are observed at/or radiating from some mound summits or crests (Fig. 14b); they

292 form, as is the case with CSPS, in response to the tensional stresses within the mound overburden

293 as it undergoes uplift and sedimentary stretch (O’Brien, 1971; Allen, 1976; Worsley and Gurney,

294 1996; Scholz and Baumann, 1997). Further growth may translate these fractures into summit

295 depressions or craters, with the overburden becoming increasingly thin (O'Brien, 1971; Allen,

296 1976; Donner, 1978; Worsley and Gurney, 1996; Scholz and Baumann, 1997; Bennike, 1998;

297 Kelly, 2001) (Figs. 14a-b). Overburden thickness scales to the thermal integrity of the mound and

298 its ice core. Once this integrity is compromised by excessive stretching, ice core thaw could be

299 engendered. Mound collapse is the end-stage of pingo evolution (O'Brien, 1971; Allen, 1976;

300 Donner, 1978; Yoshikawa et al., 1994; Worsley and Gurney, 1996; Scholz and Baumann, 1997;

301 Kelly, 2001).

302

Three geological-pathways typically are associated with the origin and development of the

303 OSPs, derived largely from field observations in Greenland: 
1) Meltwater enters the local hydrological system at points of higher elevation, i.e. mountain slopes or valley walls, and migrates to lower elevations by means of sub-or intra-permafrost channels. The meltwater emerges where the permafrost is sufficiently thin or the hydraulic pressure is sufficiently high to uplift the near-surface/surface terrain into a mound (Müller, 1963; Bennike, 1998). An ice core forms as the water's near-surface exposure to perennial freezing evolves (Müller, 1963); or,

2) Meltwater forms basally under the snout of a surging or a receding glacier and migrates down-valley to the mound site(s) by means of near-surface faults, fractures or sub/intrapermafrost channels. Mound formation occurs where the permafrost is relatively thin and most susceptible to the hydraulic pressure generated by the valley-midst topography linking glaciers to mound sites (e.g. Müller, 1963; Yoshikawa et al., 1994; Yoshikawa and Harada, 1995); or,

3) Deeply-seated and possibly geothermally-driven water migrates to the surface through local or regional faults. The pressure is sufficient to uplift near-surface sediments, forming a mound and an underlying ice core as freezing iterates itself annually (e.g. O’Brien, 1971; Allen, 1976; Yoshikawa and Harada, 1995; Worsley and Gurney, 1996; Scholz and Baumann, 1997).

\section{Glacial landscapes on Earth}

\subsection{Glaciers}

Glaciers comprise perennial and net accumulations of water-ice precipitated episodically from the atmosphere and are classified according to their size and geographical context (e.g. Barry and Gann, 2011) (Figs. 15a-c). Valley glaciers, for example, are relatively small in scale compared to ice sheets and caps and their flow is constrained by the local topography (e.g. Sugden and John, 
327 1976). Flow movement is the result of gravity and the internal deformation of ice (e.g. Barry and

328 Gann, 2011).

$329 \quad 5.2$ Moraines

330 Glacial moraines are composite landforms, formed and modified by a range of processes

331 operative at glacial margins; these include glacio-tectonism, bulldozing/pushing, squeezing,

332 freeze-on, melt-out, glaciofluvial, and gravity-driven processes (e.g. Benn and Evans, 2010) (Figs.

333 15a, c). Irrespective of their genesis, moraines may comprise unsorted glacial-till whose grain-size

334 ranges from silts to boulder-sized clasts (Fig. 15b) and whose uneven distribution may engender

335 topographical irregularity (e.g. Shakesby, 1989) (Figs. 15 a, c). The till is formed by the erosion

336 and entrainment of sediment by glacial processes (van der Meer et al., 2003).

337 Moraines are referenced according to context and composition (e.g. Hambrey, 1994;

338 Easterbrook, 1999) (Figs. 15a, c). Terminal or ice-marginal moraines are the outermost ridges

339 which mark the maximum horizontal extent of a glacier (e.g. Hambrey, 1994; Summerfield, 1991).

340 Depending on the orientation of moraines to ice flow, terminal and recessional moraines may be

341 further divided into lateral or frontal moraines, or latero-frontal moraines where the entire tongue

342 is demarcated by ridges (Benn and Evans, 2010). Serialised recessional-moraines are not unusual

343 when multiple retreats and pauses of glaciers occur (e.g. Easterbrook, 1999) (Fig. 15a, c).

$344 \quad 5.3$ Lineations (small-large scales)

345 Centimetre-scale striations, sub-metre-to metres-wide grooves and polished bedrock are

346 the product of glacial abrasion at varying scales of width and depth (e.g. Hoppe and Schytt, 1953;

347 Witkind, 1978; Lliboutry, 1994; Fjellander et al., 2006) (Fig. 16). Individual striations are gouged

348 into the bedrock by single and relatively small clasts embedded and entrained in basal ice as it 349 moves downstream (Påsse, 2004). Grooves, formed similarly, are the work of larger-sized clasts, 
350 cobbles and boulders. The clasts, cobbles and boulders are quarried from nearby rock walls and,

351 as rock contact wears out and blunts their erosive competences, the distance covered by their

352 gouging is proportional to the size of the clasts and cobbles (Lliboutry, 1994). Polished bedrock is

353 the result of a much more comprehensive and evenly distributed type of wear, albeit by fine-

354 grained debris or clean ice, across the entire face of the exposed bedrock (Påsse, 2004).

$355 \quad$ Fluted ridges or flutes are linear (constructional) bedforms comprised of sub-glacial 356 sediments that have undergone post-depositional deformation (Boulton, 1976) (Figs. 17a-b).

357 Bracketed by shallow furrows or grooves, the flutes are low, typically $\leq 5 \mathrm{~m}$ in relative elevation 358 above the surrounding sediments (Hoppe and Schytt, 1953; Baranowksi, 1970; Glasser and 359 Hambrey, 2001; Benn and Evans, 2010), decimetres to metres wide, and tens of metres to hundreds 360 of metres long (Hoppe and Schytt, 1953; Roberson et al., 2001). When observed in groups, 361 individual flutes often exhibit metres-to multi-metres of separation (Hoppe and Schytt, 1953); the 362 groups also trend normal to the glacier's terminus and in line with the flow of the glacier (Roberson 363 et al., 2001). Although not the case in all instances, some flutes exhibit cobbles and boulders whose 364 long-axes also point in the direction of the ice movement (Hoppe and Schytt, 1953; Boulton, 1976). 365 Flutes develop beneath temperate glaciers and their warm-based ice, as till is pressured into 366 lee-side cavities of sub-glacially transported boulders and cobbles (e.g. Hoppe and Schytt, 1953; 367 Hart, 1998; Glasser and Hambrey, 2001; Benn and Evans, 2010). Flute width is consistent 368 throughout the long axes and proportional to the boulders and cobbles that reside upslope of them 369 (Glasser and Hambrey, 2001). Bracketing furrows form adjacent to the ridges as the result of till 370 migration into the lee-side boulder and cobble cavities (Boulton, 1976; also, Baranowski, 1970).

371 Since flute/furrow genesis is uniquely sub-glacial, assemblages thereof rarely are observed beyond 372 current or past glacial forelands (Glasser and Hambrey, 2001). 
Boulder trains are linear clusters of erratic boulders that track the flow lines of former

374

375

376

377

378

379

380

381

382

383

384

385

386

387

388

389

390

391

392

393

394

395 glaciers (Augustinus et al., 1997; Evenson et al., 2009; Hall and Phillips, 2006; Darvill et al., 2015)

(Figs. 18a-b). One of the two principal formation-hypotheses proposes that the constituent boulders are plucked from rock outcrops, cliffs or tors and, subsequently, are dragged and deposited linearly (albeit proximally) by basal ice as it flows downstream (Hall and Phillips, 2006; Phillips et al., 2006; Darvill et al., 2015). According to this hypothesis, the distal deposition of the boulders is neither expected nor observed (Augustinus et al., 1997; Hall and Phillips, 2006; Phillips et al., 2006; Darvill et al., 2015). Closely-set and cascadingly-smaller boulders downslope of the larger lead boulder upslope is not infrequent, since the lead boulder would protect the lesser-sized boulders from further drag, and would be consistent with this hypothesis (Augustinus et al, 1997; Hall and Phillips, 2006).

An alternate formation-hypothesis suggests that boulder trains are vestigial to rock avalanches, comprise markers of supraglacial transportation and are spread linearly by ice flow onto moraines (Evenson et al., 2009; Darvill et al., 2015). Distal deposition is not inconsistent with this hypothesis (Evenson et al., 2009). However, trains composed of cascadingly-smaller boulders downslope of the lead boulder upslope are explained less easily.

Mega-scale glacial lineations comprise a suite of parallel grooves and ridges that are aligned with the antecedent flow of ice (Clark et al., 2003; Storrar and Stokes, 2007; Benn and Evans, 2010; Fu et al., 2012) (Fig. 19). They exhibit up to tens of metres of height, hundreds of metres of width and as much as 100 km of length (Hättestrand and Clark, 2006; Fowler, 2010; Fu et al., 2012). The leading formation-hypothesis assumes that entrained boulders or rocks in basal ice act as "keels" that plough through soft sediments, carve elongate grooves and squeeze sediment into the intervening ridges (Clark et al., 2003). 

411 fill and polygon origin.

412

\subsection{Polygonised depressions}

\section{Landscape interpretation}

\subsection{Basin-surface and ridge/trough nested polygons}

The morphology and metres-scale of the basin-surface polygons and the ridge and trough nested polygons in our study region are consistent with polygons formed by thermal-contraction in permafrost on Earth (e.g. Lachenbruch, 1962; Oehler et al., 2016) and, possibly, elsewhere on Mars (e.g. Pechmann, 1980; Costard and Kargel, 1995; Seibert and Kargel, 2001; Soare et al., 2008; Levy et al., 2009a,b; Oehler et al., 2016). However, where only HCPs or polygons that exhibit no topographical variance between centres and margins are observed, as is the case with the basin-surface polygons, identifying marginal fill is neither simple nor straightforward. Planview observations derived of HiRISE imagery, even at the best resolution and magnification, are equivocal; the aggradational and degradational morphologies of sand- or ice-wedge polygons are relatively congruent when observed remotely.

On Earth, ground truth invariably underlies the discrimination of the two polygon types.

On Mars, by contrast, a landscape-scale evaluation and conciliation of individual features (e.g. Baker, 2003; Hauber et al., 2011) may comprise the most effective pathway for deducing marginal

The polygonised terrain is our study region is punctuated at some locations by shallow circular to sub-circular depressions (Fig. 5c), lineated and parallel to sub-parallel variances of topography (Figs. 5a-b) and, in one kilometres-scale basin, cascading equator-ward scarps (Fig. 4). In permafrost regions on Earth polygonised terrain with similar variances of topography typically occur where/when ice-rich terrain undergoes thermal degradation, deflation or 
418 subsidence, and volumetric loss. These losses are the work of evaporation and/or meltwater 419 migration. Thaw-derived run-off channels often facilitate the latter.

On Mars, contrarily, none of the thermokarst-like landscapes exhibit run-off channels. If 421 and when the atmospheric vapour-pressure at the mid-latitudes is low (relative to the vapour 422 pressure of near-surface ice), and the boundary conditions are well below the triple point of water, 423 the most plausible agent of ice loss would be sublimation (e.g. Morgenstern et al., 2007; Lefort et 424 al., 2009, 2010; Ulrich et al., 2010; Séjourné et al., 2011; Dundas et al., 2015; Dundas, 2017).

This having been said, hypotheses concerning ice enrichment and ice depletion need not 426 be univocal in identifying plausible environmental triggers. There is no conceptual or geological 427 inconsistency in proposing ice enrichment by the freeze-thaw cycling of water and ice-depletion 428 by sublimation. Inconsistencies are reared, however, if and when ice enrichment is explained by 429 means of sublimation and adsorption cycles.

430 For example, the heterogenous distribution of excess ice in terrestrial landscapes is the 431 result of highly-localised differences in sedimentary permeability, pore space and tortuosity. In 432 turn, this facilitates or impedes the formation of segregation ice or ice lenses and the heaved 433 deformation of terrain surfaces. Hypotheses favouring the origin and development of excess ice 434 by adsorption-diffusion cycles implicitly assume a latitudinal homogeneity in the composition of 435 near-surface regolith and of its ice richness (Mellon and Jakosky, 1993; also, Dundas et al, 2015). 436 These hypotheses are weakened by two constraints.

437 First, and notwithstanding questions concerning the plausibility of regolith homogeneity 438 on the scale assumed here, diffusion-adsorption cycles are self-limiting. Once the pore space of 439 near-surface regolith has become saturated with adsorbed water ice, transport to a sub-adsorbed 440 ice depth is choked off (Clifford, 1993; Mellon and Jakosky, 1993). As such, the decametres of 
441 possible thermokarst depth observed in one of our study-region basins, and elsewhere on Mars

442 (e.g. Morgenstern et al., 2007; Lefort et al., 2008; Séjourné et al., 2011), lie beyond the explanatory

443 reach of the adsorption-diffusion hypothesis. The highly iterative freeze-thaw cycling of water

444 would not be proscribed similarly.

$445 \quad 6.3$ Ridge and trough terrain

446 Overlying portions of the polygonised surface of the basins in our study region is terrain 447 comprised of interconnected ridges and troughs, also referenced as brain terrain in the literature 448 (e.g. Levy et al., 2009a, b) (Figs. 6, 7a-c). They are metres in elevation and metres to decametres 449 in width. Basin-ward flanks of the ridge and trough assemblages are less dense and thick than the 450 assemblages closer to the basin margins. Outcrops of these assemblages, possibly remnants of 451 basin coverage by them that was more extensive than today, also are observed (Fig. $7 \mathbf{b})$. The ridges 452 and troughs could be the ablated remnants of an icy mantle (e.g. Levy et al., 2009a, b) precipitated 453 atmospherically and accumulated episodically in the Late Amazonian Epoch (e.g. Head et al., 454 2003; Milliken et al., 2003; Madeleine et al., 2009; 2014; Shorghofer and Forget, 2012).

$455 \quad 6.4$ Mounds

456 Decametre-wide, metres-high and circular to sub-circular mounds are observed throughout 457 the polygonised basins in our study region (Figs. 3b, 5, 8a-d). Mound summits show fracturing 458 and possible depletion. Mound surfaces, as noted above, exhibit polygonization. Mound 459 distribution, typically, is clustered. Isolated outliers are infrequent. No mounds are observed on 460 the terrain adjacent to the basin.

461 Nearby, i.e. the Moreux impact-crater region (Soare et al, in press), and elsewhere, i.e. the 462 mid-latitudes of Utopia Planitia (Soare et al., 2005; 2013; 2020; Dundas et al., 2008; de Pablo and 463 Komatsu, 2009), equatorial Athabasca Valles (Burr et al., 2005; Page and Murray, 2006; Balme 
464 and Gallagher, 2009), and in the Argyre impact-crater region (Soare et al., 2014), pingo-like

465 mounds that show similarities of size, shape, polygonization and possible degradation have been

466 observed. Mound origin is deduced from and categorized by mound location. For example, if the

467 mounds are nested in plains, basins and thermokarst-like depressions then a hydrostatic origin is

468 hypothesized (e.g. Soare et al., 2005; 2013; 2020; Burr et al., 2005; Balme and Gallagher, 2009).

469 A slope-side location in the Argyre region, adjacent to graben-like cavities and possible paleo-

470 discharges of water, highlights the one location where a hydraulic origin for the pingo-like mounds

471 has been hypothesized (Soare et al., 2014).

472

6.5 Bow-like ridges and boulder/cobble lineations

473

Unlike periglacial landscape features such as small-sized polygons and pingo-like mounds

474 whose form does not necessarily constrain one and only one possible origin, the connexion

475 between process and form is less equivocal with regard to the bow-like ridges that populate the

476 (inner) eastern margin of the two main basins in our study zone. For example, the ridges are

477 topographically-irregular through their fronts and flanks, are sometimes serialized and are

478 distributed proximally to possible valley-constrained flows (Figs. 9, 10a). These traits are

479 commonplace amongst glacial moraines on Earth (Figs. 15a, c). On Mars, the moraine-like ridges

480 are thought to be no less diagnostic of glaciation, especially when they are observed amidst other

481 glacier-like forms such as lineated valley fill and sinuous esker-like channels (e.g. Arftstrom and

482 Hartmann, 2005; Banks et al., 2008; Dickson et al., 2008; Head et al., 2010; Hubbard et al., 2011,

483 2014; Souness et al., 2012; Brough et al., 2016; Hepburn et al., 2020).

Speculation about the origin of boulder-alignments on Mars is wide-ranging and stretches

485 from periglacially induced self-sorting through to mass wasting or englacial flow (e.g. Banks et

486 al., 2008; Hubbard et al., 2011, 2014). A number of variables weigh against (periglacial) self- 
487 sorting. First, decametre-scale boulders are not observed in self-sorted landscapes on Earth; 488 convectional forces and frost heave substantially greater than those expressed terrestrially would 489 be required for stripes comprised of these large boulders to form. Second, some of the boulder 490 alignments and spatially-associated grooves are contiguous with grooves in the basin-adjacent 491 terrain. This would be more consistent with an erosive origin, proximally, and to mass movement 492 or entrainment than with freeze-thaw cycling and the work of periglaciation. Third, the density of 493 boulder distribution and of boulder alignments decreases as the distance to the basin's edge 494 increases. This too points to the spatial proximity of source material and away from in situ self495 sorting. With regard to mass wasting, it is not clear that the gravity-induced flow or slide of boulder 496 material in and of itself could engender the tightly distributed lines of boulders and grooves 497 observed here.

By way of scale, the basin-margin grooves are too narrow and shallow to fit the terrestrial 499 definition of mega glacial-lineations, as well as too wide and deep to be deemed striations (Fig. 500 10b). Setting aside these scale-based definitions, the grooves could have been gouged by glacially501 entrained boulders whose size befits the actual width and depth of the former. This hypothesis also 502 would be consistent with the contiguous gouging observed upslope of the grooves in the basin503 adjacent terrain. Where the mega-lineation explanation falls short, however, is with regard to the 504 presence of groove-nested or -adjacent boulders at various basin-margin locations throughout our 505 study region. This suggests deposition, not erosion, and the possibility that the lineated grooves 506 and boulder lineations are the result of two separate and distinct glacial regimes.

As noted above, some boulder alignments do exhibit smaller boulders downslope of larger ones and, in as much the distribution and density of boulder alignments increases with its proximity 509 to an upslope source on the basin-adjacent terrain, they could be boulder trains (Figs. 10b-c). At 
510 the same time, the entrainment of boulders and the gouging of erosive grooves or furrows is not a

511 keynote characteristic of boulder trains. Once again, a separate and distinct glacial regime would

512 have to be inferred as a complement to the boulder-train hypothesis for its plausibility to be

513 warranted.

514 Of the glacially-associated explanations of boulder alignment, the glacial-flute hypothesis

515 befits the geological context of our observations most closely For example, the hypothesis

516 concurrently encompasses the formation of small-scale grooves and of adjacent terrain that is

517 slightly elevated and bouldered, as seen in Fig. 10b. The adjacency of boulder sources proximal

518 to the possible flutes (Fig. 10d) offers tertiary support of the hypothesis, although this would be 519 equally supportive of the boulder-train hypothesis.

520 The ridge and trough terrain is thought to comprise the sublimated remnants of surface ice 521 on Mars that is precipitated atmospherically (e.g. Levy et al,, 2009a, b); as such, it could be 522 considered artefactual to glaciation. However, this terrain has no observed analogue on Earth and 523 questions concerning the origin of its distinctive and unique morphology remain largely 524 unanswered.

\section{7. Age-estimates and the temporal-ordering of local periglaciation and glaciation}

\section{$526 \quad 7.1$ Glacial Stade I (inferred not observed)}

527 The clastic composition of the terrain incised by the small-sized polygons and the 528 thermokarst-like depressions is unknown. However, for ice enrichment and wedging to occur the 529 terrain would have needed to incorporate relatively fine-grained material. Then, as now, the 530 removal, transport and deposition of regolith by the work of wind is a key player in Mars' dynamic 531 surface-environment. Volcanic ash or loess, for example, could have been brought to the region 532 by aeolian activity sufficient to form a thick surface to depth horizon or sets of horizons (e.g. 
533 Greeley and Williams, 1994; Bridges et al., 2010; Séjourné et al., 2012; Bridges and Muhs, 2012;

534 Skinner et al., 2012; Soare et al., 2014; Smalley et al., 2019).

535

The possibility that variances of obliquity and eccentricity have facilitated and induced the

536 atmospheric precipitation of dusty snow/ice and its surface accumulation at the northern mid-

537 latitudes throughout the Late Amazonian Epoch is well documented in the literature (e.g. Jakosky

538 et al., 1995, Head et al., 2003, Laskar et al., 2004; Madeleine et al., 2009, 2014; Shorghofer and

539 Forget, 2012). Were this dusty/ice snow to have undergone thaw, with meltwater migrating into

540 regolith composed of volcanic ash or loess, this would have framed an ideal set of boundary

541 conditions for the freeze-thaw cycling of that meltwater (Soare et al., 2014). We define this

542 hypothesized period of glaciation and deglaciation as Glacial Stade-I, and suggest that it preceded

543 the Type-1 polygonization of the currently-exposed basin surfaces in our study region.

$544 \quad 7.2$ Periglacial Period I

545 Age estimates of these Type-1 polygonised basins derived from the evaluation of CSFD 546 raise the possibility that the polygons are as old as $100 \mathrm{Ma}$ (see Appendix A, Figs. 20a-e). We 547 define this formation period as Periglacial Period-I (PP-I). The $100 \mathrm{Ma}$ age estimate, if valid, is 548 roughly an order of magnitude greater than the relatively recent age estimate of the fragmented or 549 degraded terrain, possibly icy in origin, that overlies the Type-1 polygons at some locations (Fig. $5507 \mathbf{c})$.

7.3 Glacial Stade II (possible remnants observed); Periglacial Period II

Fragmented-terrain members include: networked ridge and trough structures (i.e. brain 553 terrain) pingo-like mounds and mound remnants; and, etched Type-2 polygons that incise the 554 mounds, mound remnants and adjacent terrain (Figs. 7a-c, 8a-d). Based on this relative 555 stratigraphy and the CFSD of the brain terrain, we suggest that the Type-2 polygons, possibly the 
mounds as well, regardless of whether they are open or closed, formed during a second and more recent periglacial period (PP-II), i.e. 1 - 10 Ma, than PP-I. Moreover, if brain terrain comprises glacial residue whose distribution varies between dense to sparse throughout the Type-1 polygonised basins, then the antecedent presence of an icy mass that covers the basins completely (Glacial Stade-II) does not seem implausible. Left open is the question of whether the thermokarstic depressions formed during PP-I or PP-II.

All of the observed thermokarst-like depressions in the valley basins are incised by Type1 polygons, many of which show high-centres. We suggest that the devolatilized depressions formed prior to their polygonization during PP-I. Whether devolatilization was the work of thaw or sublimation is moot, as long as one differentiates between periods of ice enrichment, which require water to undergo freeze-thaw cycling, and periods of ice loss, which do not. Arguably, devolatilization could have postdated GS-II, been concurrent with PP-II and not involved the freeze-thaw cycling of water. Similarly large offsets of time between enrichment and depletion are commonplace, for example. amidst late Quaternary Epoch and Holocene era permafrost landscapes on Earth (e.g. Rampton, 1973, 1988). On the other hand, devolatisation of metres-deep ice-rich terrain could have occurred within a relatively short period of time during PP-II, as has happened throughout the very late Holocene era (e.g. Farquaharson et al., 2019), when and if conditions of water meta-stability arose in our study region.

\subsection{Glacial Stade III}

On the eastern margin of the southernmost Type-1 polygonised basin in our study zone some of the bouldery and debris-covered ridges, possibly moraines, intercept ridge and trough remnants. The amplitude and mass of the bouldery ridges is greater at these contacts than where the ridge and trough remnants are absent. This apparent push-morphology suggests that the 
579 remnants predate the bouldery ridges (Fig. 11). As such, the moraine-like structures could be

580 artefacts of a separate and distinctly successive period of glaciation, i.e. Glacial Stade III (GS-

581 III).

582 To the east and upslope of the bouldery ridges, lineations reminiscent of glacial flutes and

583 boulder-trains are observed (Figs. 10a-b). Some of them extend almost to the bouldery and

584 moraine-like ridges themselves (Fig. 10c). They too could be features associated with GS-III.

585 Interestingly, the possible flutes and boulder trains superpose polygons whose shape, size, texture

586 and networked distribution matches the Type-1 polygons that populate the adjacent basin to the

587 west. At some locations, the two sets of polygons intersect and we interpret the sub-flute polygons

588 to be formationally concurrent with the Type-1 polygons that incise the basin polygons (Fig. 2c).

589 8. Conclusion

590

Using cross-cutting relationships, relative stratigraphy and crater-size frequency

591 distributions (CSFDs) we have identified landscape features within our study region that point to

592 the existence of three disparate albeit temporally intertwined glacial stades and two periglacial

593 periods. Age estimates of the earliest polygons, Type-1, and of the polygonally-incised

594 thermokarst-like depressions in our basin-based landscapes suggest an origin that could be 100

595 Ma. This is millions of years older and almost an order of age magnitude beyond that of the more

596 youthful Type-2 polygons.

597

Heretofore, much of the discussion about periglaciation on Mars has focused on its relative

598 recentness and the glaciation that preceded it (e.g. Mustard et al., 2001; Head et al., 2003; Levy et

599 al., 2009a, b; Séjourné et al., 2011; Schon et al., 2012; Sinha and Murty, 2015). The older

600 estimation of periglaciation in our study region and the intertwined chronology of two (possible)

601 periglacial periods and three glacial stades documented here suggests that the cycling of the two 
602 environment types could be much more Earth-like and extend much more deeply into Mars'

603 history than had been thought hitherto.

604 Appendix

605 Crater counts provide constraints on the exposure and crater retention ages of land surfaces.

606 Craters measured on the CTX image (Fig 20a.), below, across all surfaces generates a broad crater-

607 retention age for our study region immediately to the north of the Moreux impact-crater. The CSFD

608 for crater diameters larger than $200 \mathrm{~m}$ are well approximated by a $1.5 \mathrm{Ga}$ model isochron, assuming

609 the Hartmann (2005) model. This is broadly similar to the crater-count age estimate derived by

610 Sinha and Murty (2015).

611 Crater counts also were conducted on the polygonised basin-surface (area \#1) and ridge-

612 trough terrain (area \#2) in HiRISE image ESP_045349_2235 (Fig. 20b) and the polygonised

613 basin-surface (area \#3) in HiRISE image ESP_042105_2235 (Fig. 20c). The CSFDs of these areas

614 do not conform to a production function and the shallower power-law slope is indicative of a loss

615 of smaller diameter craters from the populations. This is consistent with and similar to the age

616 estimates derived of the polygonised basin surface on the eastern margin of the Moreux impact-

617 crater (Soare et al., 2020, in press).

618 Various processes may alter a crater population on Mars: burial, erosion and exhumation.

619 Each of these processes preferentially remove smaller-diameter craters from the landscape. A 620 shallower power-law slope results from the size-dependent deficit of smaller craters (see reviews 621 by Williams et al., 2018 and Rubanenko et al. 2020 and references therein for further discussion).

We note that the larger craters are shallow, possibly infilled, and polygonized consistent

623 with older, more heavily modified craters compared with the smaller diameter craters which have 
624 more pristine, bowl-shaped morphologies due to the relatively rapid loss of craters at these 625 diameters.

626

The CSFDs of the polygonised terrains in areas \#1 and \#3 (Figs. 20d-e) extend across

627 isochrons $\sim 1 \mathrm{Ma}$ at the small diameters and extend to $>10 \mathrm{Ma}$ at the large diameters with the largest

628 craters in area \#3 overlapping the $500 \mathrm{Ma}$ isochron. This suggests that the polygonised terrains

629 are older than $10 \mathrm{Ma}$, possibly as old as $\sim 100 \mathrm{Ma}$ or more. The CSFD in area \#2, composed of 630 ridges and troughs, extends from $\sim 1 \mathrm{Ma}$ to $\sim 10 \mathrm{Ma}$. Areas \#1 and \#3 generally contain larger

631 diameter craters than area \#2. This points to the polygonised terrain being older than the latter, 632 possibly by 10 s to 100 s $\mathrm{Ma}$, and is consistent with the observed overprinting of the polygonised 633 basin-surface by the ridge and trough terrain in HiRISE image ESP_045349_2235. The similar 634 density of the more pristine, bowl-shaped craters on all three areas at the smaller sizes indicates 635 that the characteristic time of the retention of these smaller craters is more uniform across terrains.

636 References

637 Allen, C.R., O'Brien, M.G., Sheppard, S.M.F. 1976. The chemical and isotopic characteristics of 638 639

640 641 642 some northeast Greenland surface and pingo waters, Arctic and Alpine Research, 8, 3, 297317.

Arfstrom, J., Hartmann, W.H. 2005. Martian flow features, moraine-like ridges, and gullies: Terrestrial analogs and interrelationships. Icarus 174, 321-335, doi:10.1016/j.icarus.2004. 05.026 .

643 Augustinus, P.C., Gorp, D.B., Leishman, M.R., Zwartz, D. 1997. Reconstruction of ice flow across 644 the Bunger Hills, East Antarctica. Antarctic Science 9, 3, 347-354.

645 Baker, D.M.H., Head, J.W. 2015. Extensive Middle Amazonian mantling of debris aprons and 
plains in Deuteronilus Mensae, Mars: Implications for the record of mid-latitude glaciation. Icarus 260, 269-288, doi.org/10.1016/j.icarus.2015.06.036.

Baker, V.R. 2003. Icy Martian mysteries. Nature 426, 779-780, doi.org/10.1038/426779a.

Balme, M.R, Gallagher, C. 2009. An equatorial periglacial landscape on Mars. Earth and Planetary Science Letters 285, 1-15, doi.10.1016/j.eps1.2009.05.031.

Banks, M.E., et al. 2008. High Resolution Imaging Science Experiment (HiRISE) observations of glacial and periglacial morphologies in the circum-Argyre Planitia highlands, Mars. Journal of Geophysical Research 113, E12015, doi:10.1029/2007JE002994,

Baranowski, S. 1970. The Origin of Fluted Moraine at the Fronts of Contemporary Glaciers. Geografiska Annaler. Series A, Physical Geography 52, 1, 68-75.

Barry, R.G, Gan, T-Y. 2011. The global cryosphere: past, present and future. Cambridge: Cambridge University Press.

Benn, D., Evans, D. 2010. Glaciers and glaciation, London UK, Hooder Education.

Bennike, O. 1983. Pingos in Peary Land, North Greenland. Bulletin of the Geological Society of Denmark 32, 97-99.

Bennike, O. 1998. Pingos at Nioghalvfjerdsfjorden, eastern North Greenland. Geology of Greenland Survey Bulletin 180, 159-162.

Bjarnadóttir, V. 2015. Flutes in the forefield of Nordenskiöldbreen, Svalbard. BSc Thesis. Faculty of Earth Sciences School of Engineering and Natural Sciences University of Iceland, Reykjavík, 35 p.

Black, R.F. 1954. Permafrost - a review. Bulletin of the Geological Society of America 85, 839856.

Boulton, G.S. 1976. The origin of glacially fluted surface observations and theory. Journal of 
Glaciology. 17, 76, 287-309.

Bridges, N.T., et al. 2010. Eolian bedforms, yardangs, and indurated surfaces in the Tharsis Montes as seen by the HiRISE camera: evidence for dust aggregates. Icarus 205:165-182, doi.org /10.1016/ j.icarus.2009.05.017.

Bridges, N.T., Muhs, D.R. 2012. Duststones on Mars: source, transport, deposition and erosion. Sedimentary Geology of Mars, SEPM special issue 112, 169-182.

Brough, S., Hubbard, B., Hubbard, A. 2016. Former extent of glacier-like forms on Mars. Icarus 274, 37-49, doi.org/10.1016/j.icarus.2016.03.006.

Burr, D.M., Soare, R.J., Wan Bun Tseung, J.M., Emery, J. 2005. Young (late Amazonian), near surface, ground ice features near the equator, Athabasca Valles, Mars. Icarus 178, 56-73.

Clark, C.D., Tulczyk, S.M., Stokes, C.R., Canals, M. 2003. A groove-ploughing theory for the production of mega-scale glacial lineations, and implications for ice-stream mechanics. Journal of Glaciology 49, 165, 240-256.

Costard, F.M., Kargel, J.S. 1995. Outwash plains and thermokarst on Mars. Icarus 114, 1, 93112, doi.10.1006/icar.1995.1046.

Cruickshank, J.G., Colhoun., E.A. 1965. Observations on Pingos and Other LandForms in Schuchertdal, Northeast Greenland. Geografiska Annaler. Series A, Physical Geography 47, 4, 224-236.

Czudek, T., Demek, J. 1970. Thermokarst in Siberia and its influence on the development of lowland relief. Quaternary Research 1, 103-120.

De K. Leffingwell, E. 1915. The dominant form of ground-ice on the north coast of Alaska. The Journal of Geology 23, 7, 635-654.

De Pablo, M.A., Komatsu, G. 2009. Possible pingo fields in the Utopia basin, Mars: Geological 
and climatical implications. Icarus 49-74, doi:10.1016/j.icarus.2008.09.007.

Dickson, J.L, Head, J.W., Marchant, D.R. 2008. Late Amazonian glaciation at the dichotomy boundary on Mars: Evidence for glacial thickness maxima and multiple glacial phases. Geology 36, 5, 411-414; doi:10.1130/G24382A.

Donner, J. 1978. Holocene history of the west coast of Disko, central west Greenland. Geografiska Annaler. Series A, Physical Geography 60, 12, 63-72.

Dundas, C.M., Mellon, M.T., McEwen, A.S., Lefort, A., Keszthelyi, L.P., Thomas, N., 2008. HiRISE observations of fractured mounds: possible martian pingos. Geophysical Research Letters 35, L04201, doi.org/10.1029/2007GL031798.

Dundas, C.M., McEwen, A.S. 2010. An assessment of evidence for pingos on Mars using HiRISE. Icarus 205, 1, 244-258, doi.org/10.1016/j.icarus.2009.02.020.

Dundas, C.M., Byrne, S., McEwen, A.S. 2015. Modeling the development of Martian sublimation thermokarst landforms. Icarus 262, 154-169, doi.org/10.1016/j.icarus.2015.07.033.

Dundas, C.M. 2017. Effects of varying obliquity on Martian sublimation thermokarst landforms. Icarus $281,1,115-120$, doi.org/10.1016/j.icarus.2016.08.031.

Easterbrook, D.J. 1991. Surface processes and landforms. New Jersey: Prentice Hall.

Evenson, E.B., et al. 2009. Enigmatic boulder trains, supraglacial rock avalanches, and the origin of “Darwin's boulders,” Tierra del Fuego. GSA Today 19, 12, doi:10.1130/GSATG72A.1.

Farquharson, L.M., Romanovsky, V.E., Cable, W.L., Walker, D.A., Kokelj, S.V., Nicolsky, D. 2019. Climate Change Drives Widespread and Rapid Thermokarst Development in Very Cold Permafrost in the Canadian High Arctic. Geophysical Research Letters 6681-6689, doi.org/10.1029/2019GL082187.

Fjellanger, J., Sørbel, L., Linge, H., Brook, E.J., Raisbeck, G.M., Yiou, F. 2006. Glacial survival 
of blockfields on the Varanger Peninsula, northern Norway. Geomorphology 82, 255-272.

Fowler, A.C. 2010. The formation of subglacial streams and mega-scale glacial lineations. Proceedings of the Royal Society 466, 181-3201, doi:10.1098/rspa.2010.0009.

French, H.M. 2007. The periglacial environment, $3^{\text {rd }}$ ed., J. Wiley \& Sons, West Sussex, England, 458 p.

French, H.M., Guglielmin, M. 2000. Frozen ground phenomena in the vicinity of Terra Nova Bay, northern Victoria Land, Antarctica: a preliminary report. Geografiska Annaler 82, A, 513526.

Frey, H.V., Roark, J.H., Shockey, K.M., Frey, E.L., Sakimoto, S.E.H. 2002. Ancient lowlands on Mars, Geophysical Research Letters 29, 10, 1384,10.1029/2001GL013832.

Fu, P., Heyman, J., Hättestrand, C., Stroeven, A.P., Harbo, J.M. Glacial geomorphology of the Shaluli Shan area, southeastern Tibetan Plateau. Journal of Maps 8:1, 48-55, doi:10.1080/ 17445647.2012.668762.

Glasser, N.F., Hambrey, M.J. 2001. Styles of sedimentation beneath Svalbard valley glaciers under changing dynamic and thermal regimes. Journal of the Geological Society, London 158, 697-707.

Greeley, R., Williams, S.H. 1994. Dust deposits on Mars: the "Parna" analog. Icarus 110, 165177.

Grosse, G., Schirrmeister, L., Siegert, C., Kunitsky, V.K., Slagoda, E.A., Andreev, A.A., Dereviagyn, Y. 2007. Geological and geomorphological evolution of a sedimentary periglacial landscape in northeast Siberia during the late Quaternary. Geomorphology 86, 25-51, doi.10.1016/j.geomorph.2006.08.005.

Hall, A.M., Phillips, W.M. 2006. Glacial modification of granite tors in the Cairngorms, Scotland. 
Journal of Quaternary Science 21, 8, 811-830, doi:10.1002/jqs.1003.

Hallet, B., Sletten, R., Whilden, K. 2011. Micro-relief development in polygonal patterned ground in the Dry Valleys of Antarctica. Quaternary Research 75, 347-355, doi.org/10.1016/j. yqres.2010.12.009.

Hambrey, M.J. 1994. Glacial environments. UBC Press.

Harris, S.A., French, H.M., Heginbottom, J.A., Johnston, G.H., Ladanyi, B., Sego, D.C., van Everdingen, R.O. (eds.), 1988. Glossary of permafrost and related ground-ice terms. Technical Memorandum 142, Permafrost Subcommittee, National Research Council of Canada, 154 p.

Hartmann, W.K. 2005. Martian cratering 8: Isochron refinement and the chronology of Mars. Icarus 174, 294-320, doi.org/10.1016/j.icarus.2004.11.023.

Hart, J.K. 1998. The deforming bed/debris basal ice continuum and its implications for the formation of glacial landforms (flutes) and sediments (melt-out till). Quaternary Science Reviews 7, 737-754.

Hättestrand, C., Clark, C.D. 2006. The glacial geomorphology of Kola Peninsula and adjacent areas in the Murmansk Region, Russia, Journal of Maps, 2:1, 30-42, doi:10.4113/ jom.2006.41.

Hauber et al. 2011. Periglacial landscapes on Svalbard: Terrestrial analogs for cold-climate landforms on Mars. The Geological Society of America Special Paper 483, 177-201, doi: 10.1130/ 2011.2483(12).

Head, J.W., Kreslavsky, M.A., Pratt, S. 2002. Northern lowlands of Mars: Evidence for widespread volcanic flooding and tectonic deformation in the Hesperian Period. Journal of Geophysical Research doi.org/10.1029/2000JE001445. 
761

762

763

764

765

766

767

768

769

770

771

772

773

774

775

776

777

778

779

780

781

782

783

Head, J.W., Mustard, J.F., Kreslavsky, M.A., Milliken, R.E., Marchant, D.R. 2003. Recent ice ages on Mars. Nature 426, 797-802, doi.10.1038/nature02114.

Head, J.W., Marchant, D.R., Dickson, J.L., Kress, A.M., Baker, D.M. 2010. Northern mid-latitude glaciation in the Late Amazonian period of Mars: criteria for the recognition of debriscovered glacier and valley glacier land-system deposits. Earth and Planetary Science Letters 294. 306-320, doi.10.1016/j.eps1.2009.06.041.

Hepburn, A. J., Ng, F., Livingstone, S. J., Holt, T., Hubbard, B. 2020. Polyphase mid-latitude glaciation on Mars: Chronology of the formation of superposed glacier-like forms from crater-count dating. Journal of Geophysical Research 125, e2019JE006102, doi.org/10. 1029/2019JE006102.

Hoppe, G., Schytt, V. 1953. Some Observations on Fluted Moraine Surfaces Geografiska Annaler 35, 2, 105-115.

Hubbard, B., Milliken, R.E., Kargel, J.S., Limaye, A., Souness, C. 2011. Characterisation and interpretation of a mid-latitude glacier-like form: Hellas Planitia, Mars. Icarus 211, 330346, doi.10.1016/j.icarus.2010.10.021.

Hubbard, B., Souness, C., Brough, S. 2014. Glacier-like forms on Mars. The Cryosphere 8, 20472061, doi:10.5194/tc-8-2047-2014.

Hughes, O.L. 1974. Geology and permafrost in relation to hydrology and geophysics, in Proceedings of Workshop Seminar, 1974: Ottawa, Canadian National Committee, International Hydrological Decade, 21-30.

Hussey, K.M., Michelson, R.W. 1966. Tundra relief features near Point Barrow, Alaska. Arctic, $19,2,162-184$.

Jakosky, B.M., Henderson, B.G., Mellon, M.T. 1995. Chaotic obliquity and the nature of the 
martian climate. J. Geophys. Res. 100, 1579-1584.

Kneissl, T., van Gasselt, S., Neukum, G. 2011. Map-projection-independent crater size-frequency determination in GIS environments - new software tool for ArcGIS. Planetary and Space Science 59, 1243-1254, doi.org/10.1016/j.pss.2010.03.015.

Kokelj, S.V., Burn, C.R., Tarnocai, C. 2007. The Structure and Dynamics of Earth Hummocks in the Subarctic Forest Near Inuvik, Northwest Territories, Canada, Arctic, Antarctic, and Alpine Research, 39,1, 99-109, doi.org/10.1657/1523-0430(2007)39[99:TSADOE]2.0. $\mathrm{CO} ; 2$.

Lachenbruch, A.H., 1962. Mechanics of Thermal Contraction Cracks and Ice-wedge Polygons in Permafrost. GSA Special Paper 70. vol. 69 Geological Society of America, New York.

Laskar, J., Correia, A.C.M., Gastineau, M., Joutel, F., Levrard, B., Robutel, P. 2004. Long term evolution and chaotic diffusion of the insolation quantities of Mars. Icarus 170, 343-364.

Lefort, A., Russell, P.S., McEwen, A.S., Dundas, C.M., Kirk, R.L. 2009. Observations of periglacial landforms in Utopia Planitia with the High Resolution Imaging Science Experiment (HiRISE). Journal of Geophysical Research 114, E04005, doi.10.1029/ 2008JE003264.

Lefort, A., Russell, P.S., Thomas, N. 2010. Scalloped terrains in the Peneus and Amphitrites Paterae region of Mars as observed by HiRISE, Icarus, 205, 259-268, doi:10.1016/j.icarus. 2009.06.005.

Levy, J., Head, J., Marchant, D. 2009a. Concentric crater fill in Utopia Planitia: History and interaction between glacial "brain terrain" and periglacial mantle processes. Icarus 202, 462-476, doi.10.1016/j.icarus.2009.02.018.

Levy, J., Head, J., Marchant, D. 2009b. Thermal contraction crack polygons on Mars: 
Classification, distribution, and climate implications from HiRISE observations 114, E01007, doi:10. 1029/2008JE003273.

Lliboutry, L.A. 1994. Monolithologic erosion of hard beds by temperate glaciers. Journal of Geology 40, 136, 433-450.

Mackay, J.R. 1974. Ice wedge cracks, Garry Island, Northwest Territories. Canadian Journal of Earth Sciences 11, 1366-1383.

Mackay, J.R. 1986. Growth of lbyuk Pingo, Western Arctic Coast, Canada, and Some Implications

815

816

817

818 for Environmental Reconstructions. Quaternary Research 26, 1, 68-80.

Mackay, J.R. 1998. Pingo growth and collapse, Tuktoyaktuk Peninsula areas, western arctic coast, Canada: a long-term field study. Géographie physique et Quaternaire 52, 3, 1-53.

Mackay, J.R. 1999. Periglacial features developed on the exposed lake bottoms of seven lakes that drained rapidly after 1950, Tuktoyaktuk Peninsula Area, western arctic coast, Canada. Permafrost and Periglacial Processes 10, 39-63.

Madeleine, J-B., Forget, F., Head, J.W., Levrard, B., Montmessin, F., Millour, E. 2009. Amazonian northern mid-latitude glaciation on Mars: a proposed climate scenario. Icarus 203, 390-405, doi.org/10.1016/j.icarus.2009.04.037.

Madeleine, J-B. et al. 2014. Recent ice ages on Mars: the role of radiatively active clouds and cloud microphysics. Geophysical Research Letters 41, 14, 4873-4879, doi.10.1002/2014G L059861.

Malin, M.C. et al. 2007. Context Camera Investigation on board the Mars Reconnaissance Orbiter. Journal of Geophysical Research 112, E05S04, doi.org/10.1029/2006JE002808.

Marchant, D.R. et al. 2002. Formation of patterned ground and sublimation till over Miocene 
glacier ice in Beacon Valley, southern Victoria Land, Antarctica. Geological Society of America Bulletin 114, 6, 718-730.

McEwen, A.S. et al. 2007. Mars Reconnaissance Orbiter's High-Resolution Imaging Science Experiment (HiRISE). Journal of Geophysical Research 112, E05S02, doi.org/10.1029/ 2005JE002605.

McGill, G.E., Dimitriou, A.M. 1990. Origin of the Martian global dichotomy by crustal thinning in the Late Noachian or Early Hesperian. Journal of Geophysical Research doi.org/10. 1029/JB095iB08p12595.

Mellon, M.T., Jakosky, B.M. 1993. Geographic Variations in the Thermal and Diffusive Stability of Ground Ice on Mars. Journal of Geophysical Research 98, E2, 3345-3364.

Michael, G.G., Neukum, G. 2010. Planetary surface dating from crater size-frequency distribution measurements: partial resurfacing events and statistical age uncertainty. Earth and Planetary Science Letters 294, 223-229. doi.org/10.1016/j.epsl.2009.12.041.

Michael G.G., Kneiss1 T., Neesemann, A. 2016. Planetary surface dating from crater sizefrequency distribution measurements: Poisson timing analysis. Icarus 277, 279-285, doi.org/10.1016/j.icarus.2016.05.019.

Milliken, R.E., Mustard, J.F., Goldsby, D.L. 2003. Viscous flow features on the surface of Mars: Observations from high-resolution Mars Orbiter Camera (MOC) images. Journal of Geophysical Research 108, E6, 5057, doi.10.1029/2002JE002005.

Morgan, G.A., Head, J.W., Marchant, D.R. 2009. Lineated valley fill (LVF) and lobate debris aprons (LDA) in the Deuteronilus Mensae northern dichotomy boundary region, Mars: Constraints on the extent, age and episodicity of Amazonian glacial events 202, 1, 22-38, doi.org/10.1016/j.icarus.2009.02.017. 
852 Morgenstern, A., Hauber, E., Reiss, D., van Gasselt, S., Grosse, G., Schirrmeister, L. 2007.

853

854

855

856

857

858

859

860

861

862

863

864

865

866

867

868

869

870

871

872

873

874
Deposition and degradation of a volatile-rich layer in Utopia Planitia, and implications for climate history on Mars. Journal of Geophysical Research 112, E06010, doi.10.1029/ 2006JE002869.

Müller, F. 1963. Observations on Pingos. National Research Council of Canada, Ottawa, Canada, Technical Translation 1073, pp, 119.

Murton, J.B. 2001. Thermokarst sediments and sedimentary structures, Tuktoyaktuk Coastlands, western Arctic Canada. Global and Planetary Change 28, 175-192.

Murton, J.B., Worsley, P., Gozdzik, J. 2000. Sand veins and wedges in cold aeolian environments. Quaternary Science Reviews, 19, 899-922.

Mustard, J.F., Cooper, C.D., Rifkin, M.R. 2001. Evidence for recent climate change on Mars from the identification of youthful near-surface ground ice. Nature 412, 411-414, doi.10. 1038/35086515.

O’Brien, R. 1971. Observations on pingos and permafrost hydrology in Schuchert Dal, Northeast Greenland. Meddelelser om Grønland 195, 1, 20 pp.

Oehler, D., Mangold, N., Hallet, B., Fairén, .G., Le Deit, L., Williams, A.J., Sletten, R.S., Martínez-Frías, J. 2016. Origin and significance of decameter-scale polygons in the lower Peace Vallis fan of Gale crater, Mars. Icarus 277, 56-72, doi.org/10.1016/j.icarus.2016.04.038.

Osterkamp, T.E., Jorgenson, M.T., Schuur, E.A.G., Shur, Y.L., Kanevskiy, M.A., Vogel, J.G., Tumskov, V.E. 2009. Physical and Ecological Changes Associated with Warming Permafrost and Thermokarst in Interior Alaska. Permafrost and Periglacial Processes 20, 235, 256, doi:10.1002/ppp656. 
875 Page, D.P., Murray, J.B. 2006. Stratigraphical and morphological evidence for pingo genesis in 876 the Cerberus plains. Icarus 183, 46-54, doi.10.1016/j.icarus.2006.01.017.

877 Påsse, T. 2004. The amount of glacial erosion of the bedrock. Sveriges Geologiska Undersökning. $878 \quad$ Technical Report TR-04-25, 39 p.

879 Pechmann, J.C. 1980. The origin of polygonal troughs on the northern plains of Mars. Icarus 42, 880 185-210.

881

882

883

884

885

886

887 888

889 890

891 892 893 894 895 896 897

Penner, E. 1959. The mechanism of frost heaving in soils. Highway Research Board, Bulletin $225,1-22$.

Pettapiece, W.W. 1974. A hummocky permafrost soil from the subarctic of northwestern Canada and some influences of fire. Canadian Journal of Soil Science 54, 4, 343-355.

Péwé, T. 1959. Sand-wedge polygons (tessellations) in the McMurdo Sound region, Antarcticaa progress report. American Journal of Science 257, 545-552.

Phillips, W.M., Hall, A.M., Mottram, R., Fifield, L.K., Sugden, D.E. 2006. Cosmogenic ${ }^{10}$ Be and ${ }^{26} \mathrm{Al}$ exposure ages of tors and erratics, Cairngorm Mountains, Scotland: Timescales for the development of a classic landscape of selective linear glacial erosion. Geomorphology 73, 222-245, doi:10.1016/j.geomorph.2005.06.009.

Pollard, W.H., French, H.M. 1985. The internal structure and ice crystallography of seasonal frost mounds. Journal of Glaciology 31, 108, 157-162.

Rampton, V.N. 1973. The influence of ground ice and thermokarst upon the geomorphology of the Mackenzie Beaufort region, in Research in polar and alpine geomorphology, Proceedings, $3^{\text {rd }}$ Guelph Symposium on Geomorphology, edited by B.D. Fahey and R.D. Thompson, Geo. Abstracts, Norwich, UK, 43-59.

Rampton, V.N. 1988. Quaternary geology of the Tuktoyaktuk Coastlands, Northwest Territories, 
Geological Survey of Canada, Memoir 423, 98 p.

Rampton, V.N. Mackay, J.R. 1971. Massive ice and icy sediments throughout the Tuktoyaktuk Peninsula, Richards Island, and nearby areas, District of Mackenzie, Geological Survey of Canada, Paper 71-21, 16 p.

Rampton, V.N., Bouchard, M. 1975. Surficial geology of Tuktoyaktuk, District of Mackenzie, Geological Survey of Canada, Paper 74-53, 16 p.

Reznichenko, N.V., Davies, T.R., Winkler, S. 2016. Revised palaeoclimatic significance of Mueller Glacier moraines, Southern Alps, New Zealand. Earth Surface Processes and Landforms 41, 2, 196-207, doi.org/10.1002/esp.3848.

Roberson, S., Hubbard, B., Coulson, H., Boomer, I. 2001. Physical properties and formation of flutes at a polythermal valley glacier: Midre Lovénbreen, Svalbard. Geografika Annaler: Series A, Physical Geography, 93, 71-88. doi:10.1111/j.1468-0459.2011.00420.x.

Schirrmeister, L. Froese, D., Tumskoy, V., Grosse, G., Wetterich, S. 2013. Yedoma: late Pleistocene ice-rich syngenetic permafrost of Beringia. eds. S.A. Elias \& C.J. Mock, Encyclopedia of Quaternary Science, $2^{\text {nd }}$ ed., 3, 542-552.

Scholz, H., Baumann, M. 1997. An “open system“ pingo near Kangerlussuaq (Søndre Strømfjord), West Greenland, Geology of Greenland Bulletin 104-108.

Schon, S.C., Head, J.W., Fassett, C.I. 2012. Recent high-latitude resurfacing by a climate-related latitude-dependent mantle: Constraining age of emplacement from counts of small craters. Planetary and Space Science 69, 49-61, doi.org/10.1016/j.pss.2012.03.015.

Schorghofer, N., Forget, F. 2012. History and anatomy of subsurface ice on Mars. Icarus 220, 1112-1120, doi.10.1016/j.icarus.2012.07.003.

Seibert, N.M., Kargel, J.S. 2001. Small scale martian polygonal terrain: implications for liquid 
surface water. Geophysical Research Letters 28, 5, 899-902.

Séjourné, A., Costard, F., Gargani, J., Soare, R.J., Fedorov, A., Marmo, C. 2011. Scalloped depressions and small-sized polygons in western Utopia Planitia: a new formation hypothesis. Planetary and Space Science 59, 412-422, doi:10.1016/j.pss.2011.01.007.

Séjourné, A., Costard, F., Gargani, J., Soare, R.J., Marmo, C. 2012. Evidence of an eolian ice-rich and stratified permafrost in Utopia Planitia, Mars. Planetary and Space Science 60, 248254, doi:10.1016/j.pss.2011.09.004.

Shakesby, R.A., 1989. Variability in Neoglacial moraine morphology and composition, Storbreen, Jotunheimen, Norway: within-moraine patterns and their implications. Geografiska Annaler: Series A, Physical Geography 71, 1-2, 17-29.

Sinha, R.K., Murty, S.V.S. 2015. Amazonian modification of Moreux crater: Record of recent and episodic glaciation in the Protonilus Mensae region of Mars. Icarus 245, 122-144, doi.org/10.1016/j.icarus.2014.09.028.

Skinner, J.A., Tanaka, K.L., Platz, T. 2012. Widespread loess-like deposit in the Martian northern lowlands identifies Middle Amazonian climate change. Geology 40, 12, 1127-1130, doi:10.1130/G33513.1

Sletten, R.S., Hallet, B., Fletcher, R.C. 2003. Resurfacing time of terrestrial surfaces by the formation and maturation of polygonal patterned ground. Journal of Geophysical Research 108, E4, 8044, dx.doi.org/10.1029/2002JE001914.

Smalley, I., Marshall, J., Fitzsimmons, K., Whalley, W.B., Ngambi, S. 2019. Desert loess: a selection of relevant topics. Geologos 25, 1, 191-102, doi.10.2478/logos-2019-0007.

Soare, R.J., Kargel, J.S., Osinski, G.R., Costard, F. 2007. Thermokarst processes and the origin of crater-rim gullies in Utopia and western Elysium Planitia. Icarus 191, 1, 95-112, doi. 
org/10.1016/j.icarus.2007.04.018.

Soare, R.J., Osinski, G.R., Roehm, C.L. 2008. Thermokarst lakes and ponds on Mars in the very recent (late Amazonian) past. Earth and Planetary Science Letters 272, 1-2, 382-393, doi. 10.1016/j.epsl.2008.05.10.

Soare, R.J., Conway, S.J, Pearce, G., Dohm, J.M., Grindrod, P.M. 2013. Possible crater-based pingos, paleolakes and periglacial landscapes in the high latitudes of Utopia Planitia, Mars. Icarus, 225, 2, 971-981, doi.org/10.1016/j.icarus.2012.08.041.

Soare, R.J., Conway, S.J., Dohm, J.M., El-Maarry, M.R. 2014. Possible open-system pingos in and around the Argyre impact basin, Mars. Earth and Planetary Science Letters 398, 2536, doi.10. 1016/j.epsl.2014.04.044.

Soare, R.J., Conway, S.J., Williams, J-P., Gallagher, C., McKeown, L.E. 2020. Possible (closed system) pingo-thermokarst complexes at the mid-latitudes of Utopia Planitia, Mars. Icarus, doi.org/10.1016/j.icarus.2019.03.010.

Soare, R.J., Williams, J-P, Conway, S.J., El-Maarry, M.R. 2021. Pingo-like mounds and possible polyphase periglaciation/glaciation at/adjacent to the Moreux impact crater, in Mars Geological Enigmas, from the deep past through to the present. Elsevier, in press.

Souness, C.J., Hubbard, B., Milliken, R.E., Quincey, D. 2012. An inventory and population-scale analysis of martian glacier-like forms. Icarus 217, 243-255, doi.10.1016/j.icarus.2011.10. 020.

Souness, C.J., Hubbard, B. 2013. An alternative interpretation of late Amazonian ice flow: Protonilus Mensae, Mars. Icarus 225, 495-505, doi.org/10.1016/j.icarus.2013.03.030.

Storrar, R., Stokes, C.R. 2007. A Glacial Geomorphological Map of Victoria Island, Canadian Arctic, Journal of Maps, 3, 1, 191-210, doi:10.1080/jom.2007.9710838 
967 Sugden, D.E., John, B.S. 1976. Glaciers and landscape: a geomorphological approach. E. Arnold. 968 Summmerfield, M.A. 1999. Global geomorphology. Harlow, England, Pearson Education.

969 Taber, S. 1930. The mechanics of frost heaving, 9-26, in Historical perspectives in frost heave

970 research: the early works of S. Taber and G. Beskow. Special report 91-23, U.S. Army

971 Corp of Engineers, (eds.) P.B Black and M.J. Hardenburg, 1991, 159 p.

972 Tanaka, K.L., Skinner, J.A., Hare, T.M. 2005. Geological map of the northern plains of Mars, map 973 2888. Flagstaff, USGS.

974 Ulrich, M., Morgenstern, A., Günther, F., Reiss, D., Bauch, K.E., Hauber, E., Rössler, S, 975

976

977

978

van der Meer, J.J., Menzies, J., Rose, J. 2003. Subglacial till: the deforming glacier bed.

979

980 Quaternary Science Reviews, 22, 15-17, 1659-1685, doi:10.1016/S0277-3791(03)00141-

van Everdingen, R.O. 1982. Frost Blisters of the Bear Rock Spring Area near Fort Norman, NWT.

982 Arctic 35,2 243-265.

Washburn, A.L. 1973. Periglacial Processes and Environment. St Martin's Press, New York, NY, 984 p. 320 .

Williams, J.-P., van der Bogert, C.H., Pathare, A.V., Michael, G.G., Kirchoff, M.R., Hiesinger, H. 986 987 2018. Dating very young planetary surfaces from crater statistics: A review of issues and challenges. Meteoritics and Planetary Science 53, 4, 554-582, doi.org/10.1111/maps. 12924.

Witkind, I.J. 1978. Giant glacial grooves at the north end of the mission range, northwest Montana. 
Journal of Research, U.S. Geological Survey 6, 4, 425-433.

Wolfe, S.A., Morse, P.D., Neudorf, C.M., Kokelj, S.V., Lian, O.B., O'Neill, B. 2018. Contemporary sand-wedge development in seasonally frozen ground and paleoenvironmental implications. Geomorphology 215-229, doi.org/10.1016/j.geomorph. 2018.02.015.

Worsley, P., Gurney, S.D. 1996. Geomorphology and hydrogeological significance of the Holocene pingos in the Karup Valley area, Traill Island, northern east Greenland. Journal of Quaternary Science 11, 3, 249-262.

Yoshikawa, K., Harada, K. 1995. Observations on nearshore pingo growth, Adventalen, Spitsbergen. Permafrost and Periglacial Processes, 6, 4, 361-372.

Yoshikawa, K., Nakamura, T., Igarashi, Y. 1996. Growth and Collapse History of Pingos, Kuganguaq, Disko Island, Greenland. Polarforschung 64, 3, 109-113.

\section{$\underline{\text { Figures }}$}

Fig. 1. (a) Geographical context and topographical location of the study site north of the Moreux impact-crater, Mars. Top panel shows a colour-keyed digital elevation model using Mars Orbiter Laser Altimeter (MOLA) data overlain on the Thermal Emission Imaging System (THEMIS) daytime IR controlled-image mosaic. The inset gives the location of the map within the global view of Mars rendered as a hill-shaded relief version of the MOLA data.

(b) The study area in the THEMIS daytime $I R$ controlled-image mosaic. The two (red) boxes showing the location of the HiRISE images used within the fretted terrain north of Moreux crater's rim. (c-d) All of the figures and their footprints framed within Mars Reconnaissance Orbiter Context Camera (CTX) image J01_045349_2239_XN_43N316W. Image credit: Malin Space Science Systems. 
1013 Fig. 2. (a) Context image of Type-1 polygon distribution in one of the two basins studied by us.

1014

1015

1016

1017

1018

1019

1020

1021

1022

1023

1024

1025

1026

1027

1028

1029

1030

1031

1032

1033

1034
Note the overprinting of ridge and trough terrain (bottom left hand corner) and of possible moraines (top right-hand corner) located respectively at the southwestern and northeastern margins of the basin. (b) Random example of high-centred Type-1 polygons. (c-d) Example of polygonised terrain whose relative elevation and morphology are sufficiently similar to the terrain highlighted in panel (b), despite lying amidst landscape features that could be glacial in origin, for a (roughly) similar age to be ascribed (HiRISE image ESP_045349_2235, 43.405 ${ }^{0} \mathrm{~N} ; 44.108^{0}$ E, $25 \mathrm{~cm} /$ pixel). Image credit: NASA/JPL/University of Arizona.

Fig. 3. (a) Etched polygons incise terrain fragments and (b) isolated mounds which, antecedently, could have been contiguous with icy coverage of the surrounding basin (HiRISE image ESP_045349_2235, 43.405 $\mathrm{N} ; 44.108^{0}$ E, $25 \mathrm{~cm} /$ pixel). Image credit: NASA/JPL/University of Arizona.

Fig. 4. Basin-covering scarps, possibly thermokarstic in origin, with equator-ward orientation. The loss of elevation trends to the south (CTX image J01_045349_2239_XN_43N316W, 43.940 N; $43.99^{0}$ E, 5.94 m/pixel). Image credit: Malin Space Science Systems.

Fig. 5. (a) Context image of undulating, polygonised terrain, comprised of high-centred polygons. Note the longitudinal trend and the sub-parallel alignment of the undulations (b) Magnification of same. (c) Arc-like distribution of circular and sub-circular depressions within the basin-surface polygons (HiRISE image ESP_042105_2235, $43.163^{0} \mathrm{~N} ; 43.983^{0}$ E, $50 \mathrm{~cm} /$ pixel). Image credit: NASA/JPL/University of Arizona.

Fig. 6. Landscape-scale image (CTX J01_045349_2239_XN, $43.94^{0} \mathrm{~N} ; 43.99^{0}$ E, $\left.5.94 \mathrm{~m} / \mathrm{pixel}\right)$ of 
our study region. Black rectangles identify the surface coverage of the two HiRISE images highlighted by us therein. Black arrows point to the areas of the basin where the dense distribution of ridge and trough terrain begins to dissipate. Image credit: Malin Space Science Systems. Image credit: Malin Space Science Systems.

Fig. 7. (a) Partial basin-coverage by ridge and trough terrain. Note the dense distribution of etched terrain and mounds in the latter's midst. (b) Eastward transition of ridge and trough distribution: dense and continuous on the left; discontinuous, with less amplitude and mass, on the centre-left; and, possible remnants to the right, top corner (also see Fig. 8d). (c) Overprinting of the basin-surface polygons by the ridges and troughs (HiRISE image ESP_045349_2235, $43.405^{0} \mathrm{~N} ; \quad 44.108^{0} \quad$ E, $\left.25 \mathrm{~cm} / \mathrm{pixel}\right) . \quad$ Image credit: NASA/JPL/University of Arizona.

Fig. 8. Mounds and etched (Type-2) polygons. (a-c) Clustered distribution of mounds amidst the ridge and trough terrain. Note the truncation/erosion and dissection of the mounds by the ridge and trough structures, as well as the mound incision by the Type-2 polygons. (d) Density of ridge/trough distribution decreases with distance from the western flank of the basin; note outlying fragment (see Fig. 9 for context) at the far right of this tile. Collectively, these observations hint at the possibility that the basin coverage by the ridge/trough terrain could have been much more extensive than is apparent today (HiRISE image ESP_045349_2235, 43.405 $\mathrm{N} ; 44.108^{0}$ E, $25 \mathrm{~cm} /$ pixel). Image credit: NASA/JPL/University of Arizona.

Fig. 9. Kilometre-scale, longitudinal distribution of serialized raised-ridges (possible moraines), with kilometres of reach onto the basin surface at some locations (black rectangle). Note the horseshoe-shaped and etched mounds as well as the small patch of etched terrain within 
the rectangle, possibly outlying remnants of the etched terrain to the west (HiRISE image ESP 045349_2235, $43.405^{0} \mathrm{~N} ; \quad 44.108^{0}$ E, $25 \mathrm{~cm} /$ pixel). Image credit: NASA/JPL/University of Arizona.

Fig. 10. (a) Nine serialized ridges with varying degrees of amplitude and mass. Note the increased density of boulders and bouldery terrain with proximity to the basin's edge and the rockier elevated-terrain on the right flank of the image. (b) Small-scale lineations/grooves with adjacent (aligned) boulders (black arrows), consistent with presumed flow of glacier. Suggestive of Earth-like flutes. (c) Possible boulder trains (black rectangles). (d) Largerscale view of lineated train, possibly comprised of glacial flutes and/or boulder trains, linking a possible rocky source upslope with boulder-strewn fields of polygons downslope. (HiRISE image ESP 045349_2235, 43.405 ${ }^{0} \mathrm{~N} ; 44.108^{0}$ E, 25 cm/pixel). Image credit: NASA/JPL/University of Arizona.

Fig. 11. Apparent push-contact and interception of the ridge and trough terrain by moraine-like ridges (white arrows highlight contact; hollow black arrow points to one of the lobate structures). Note the loss of ridge mass and amplitude where there is no contact (top-left of figure, above the white arrows) (CTX image J01_045349_2239_XN, 43.94 ${ }^{0} \mathrm{~N} ; 43.99^{0}$ E, 5.94 m/pixel). Image credit: Malin Space Science Systems.

Fig. 12. Polygonal terrain in the Tuktoyaktuk Coastlands, Northwest Territories, Canada. (a) Icewedge polygons ( $\sim 10-20 \mathrm{~m}$ in diameter) with meltwater-filled marginal troughs slightly lower in elevation than the polygon centers. The high-centred morphology of the polygons is the result of ice-wedge degradation on the margins. Photo credits: R. Soare. (b-c). Incision of ice wedge by sand wedge and vice versa (Murton et al., 2000). (d) Panoramic and cross-sectional view of ice wedges (white arrows) in the midst of massive-ice outcrops. 
The small, surface depressions above the ice-wedge in (c) and the ice-wedge to the right, here, mark the location of bilateral polygonal troughs associated with a field of highcentered polygons. The depressions, along with the hummocky terrain above and surrounding the massive-ice, comprise thermokarst. Photo credit: R. Soare.

Fig. 13. Closed-system pingos in the Tuktoyaktuk Coastlands. (a) Thermokarst-lake drainage in ice-rich, polygonised terrain and a nascent $\operatorname{CSP}$ (plan-view) in the midst. (b) Adolescent CSP developing adjacent to the village of Tuktoyaktyuk $\left(69.4454^{\circ} \mathrm{N}, 133.0342^{\circ} \mathrm{W}\right)$. (c) Ibyuk Pingo (late winter), thought to $~ 1300$ years old (+/-200 years) (Mackay, 1986), as seen from the summit of Split Pingo. Ibyuk Pingo stands at $\sim 49 \mathrm{~m}$ above sea-level and is the 2nd highest pingo on Earth. Note the radial fracturing of Ibyuk Pingo as well as the irregular topography of the summits at both Split and Ibyuk Pingos. Photo credits: R. Soare. (d) Metre-scale (elevation) pingo rampart, the end-stage of pingo evolution. Photo credit: D.M. Burr.

Fig. 14. Open-system pingos in Greenland and Canada. (a) Two open-system pingos ( $\sim 5-10 \mathrm{~m}$ high; 20-50 m diameters) on glacial-valley floor, Mellemfjord, Disko, Central West Greenland. Braided glacio-fluvial river system dissects the valley Photo credit: Christiansen, 1995. Left-most mound displays irregularly-shaped summit depression. (b) Partially-collapsed, open-system pingo in outwash plain underlain by continuous albeit thin permafrost, Niohalvfjerdsfjorden, eastern North Greenland. Photo credit: Ole Bennike, GEUS. (c) View of Müller ice-cap terminus from summit of open-system pingo, Axel Heiberg Island, Nunavut, Canada. Small-sized thermal-contraction polygons incise terrain separating the pingo from ice-cap terminus (not clearly identifiable at this oblique angle). 
(d) Summit of Axel Heiberg pingo; note seasonal icings (off-centred from the summit apex) and glacio-fluvial river system (to left of mound). Photo credits, c-d: R. Soare.

Fig. 15. Landforms and deposition associated with glaciation on Earth. (a) Aerial view of Mueller Glacier, New Zealand, highlighted by pro-glacial lake and (marginal) moraines. White arrows indicate the crests of a large $140 \mathrm{~m}$ high Little Ice-Age latero-frontal and that of a smaller outermost terminal moraine. (b) Basal till deposited during the younger Dryas glaciation, c. 18,000 years ago, on the north shore of Loch Torridon, Scotland. Note the angular and poorly-sorted mixture of boulders and cobbles. Photo credit: M.J. Hambrey; reproduced with permission of Glaciers Online (https://www.swisseduc.ch/glaciers/). (c) Recessional-moraine assemblage at the terminus of Mueller glacier; moraines indicated by white arrows in a) are marked by orange lines. At least three moraines in sequence are identifiable. Aerial imagery in c) from the LINZ database (https://data.linz.govt.nz/).

Fig. 16. Parallel scratches in bedrock are glacial striations (western Manitoulin Island, Ontario, Canada). Scale provided by a Canadian dollar coin ("Loonie") in the centre of the photo. Location: Mississagi Lighthouse Campground,. Photo credit: A. Fyon (https://www. ontariobeneathourfeet.com/glacial-striation).

Fig. 17. (a) Glacial flute in Iceland, $75 \mathrm{~m}$ from the margin of Múlajökull glacier. The flute has three boulders at its head, all aligned with the flute's long axis. The farthest up-glacier boulder is $\sim 0.37 \mathrm{~m}$ tall. This flute is $20 \mathrm{~m}$ long, $0.21 \mathrm{~m}$ high and $0.86 \mathrm{~m}$ wide nearest its boulders. (b) Up-glacier view of multiple flutes. Meltwater flows in the depressed areas on either side of the flutes. Photo credits: L. Ives.

Fig. 18. (a) Clach Bun Rudhtair, eastern Cairngorms mountains, Scotland: The summit of the 
upper tower has been removed by ice flowing in the direction of the lineated train of boulders; the summit of the third tower is unmodified and carries weathering pits over $1 \mathrm{~m}$ deep (Hall and Phillips, 2006). (b) Boulder train highlighted by aligned and closely-set members, cascading clast-size lee of the largest boulder and in the direction of glacial flow. Photo credit, V. Bjarnadóttir.

Fig. 19. Glacial grooves, vestigial to and carved by the Laurentide Ice sheet Glacial Grooves State Monument, Kelley's Island, Ohio. Photo credit: Hill/National Snow and Ice Data Center, University of Colorado, Boulder (https://nsidc.org/cryosphere/glaciers/ gallery/grooves.html).

Fig. 20. (a) CTX image J01_045349_2239_XN, craters marked with red circles. The black boxes are the locations of the two HiRISE images in (b) ESP_045349_2235 and (c) ESP_042105_2235 with count areas outlined in black with color shading. Count areas 1 and 3 represent polygonised terrain and count area 2 is comprised of ridge and trough terrain. North is up and illumination is from the west. (d) Cumulative and (e) differential CSFDs of counts with model isochrons of Hartmann (2005) (gray curves) for $1 \mathrm{Ma}, 10 \mathrm{Ma}$, $100 \mathrm{Ma}, 500 \mathrm{Ma}$, and $3 \mathrm{Ga}$ and the model-age estimate of $1.5 \pm 0.2 \mathrm{Ga}$ for the $C T X$ counts derived by Poisson timing analysis (Michael et al., 2016). CSFDs extend across model isochrons $>10$ Ma suggesting terrains are older than $10 \mathrm{Ma}$. The crater diameters extend to larger sizes in areas 1 and 3 consistent with the polygonised terrain being older than the ridge and trough terrain. Image credit: Malin Space Science Systems, NASA/JPL/University of Arizona. 


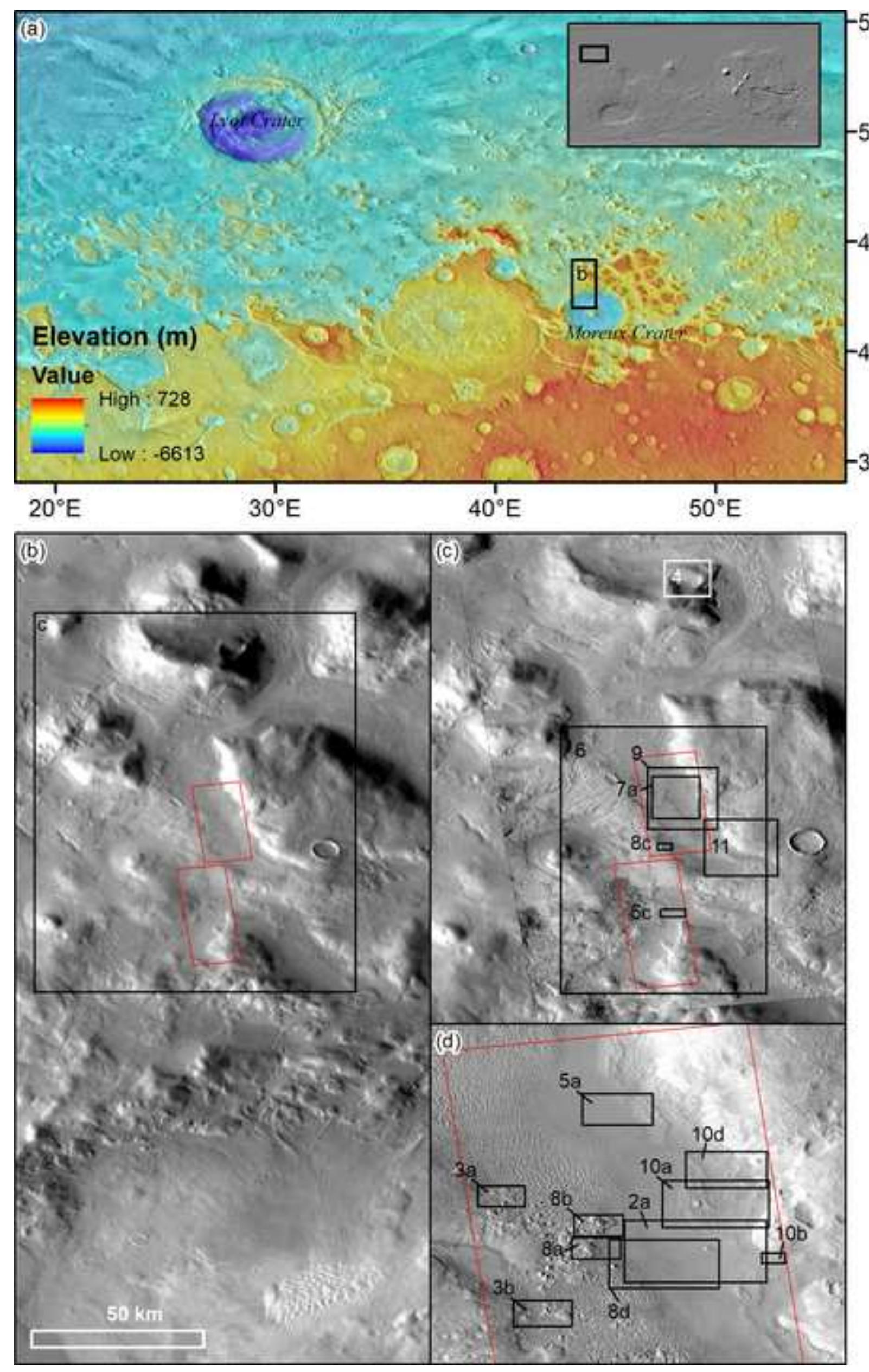

$-55^{\circ} \mathrm{N}$

$-45^{\circ} \mathrm{N}$ $-40^{\circ} \mathrm{N}$ 


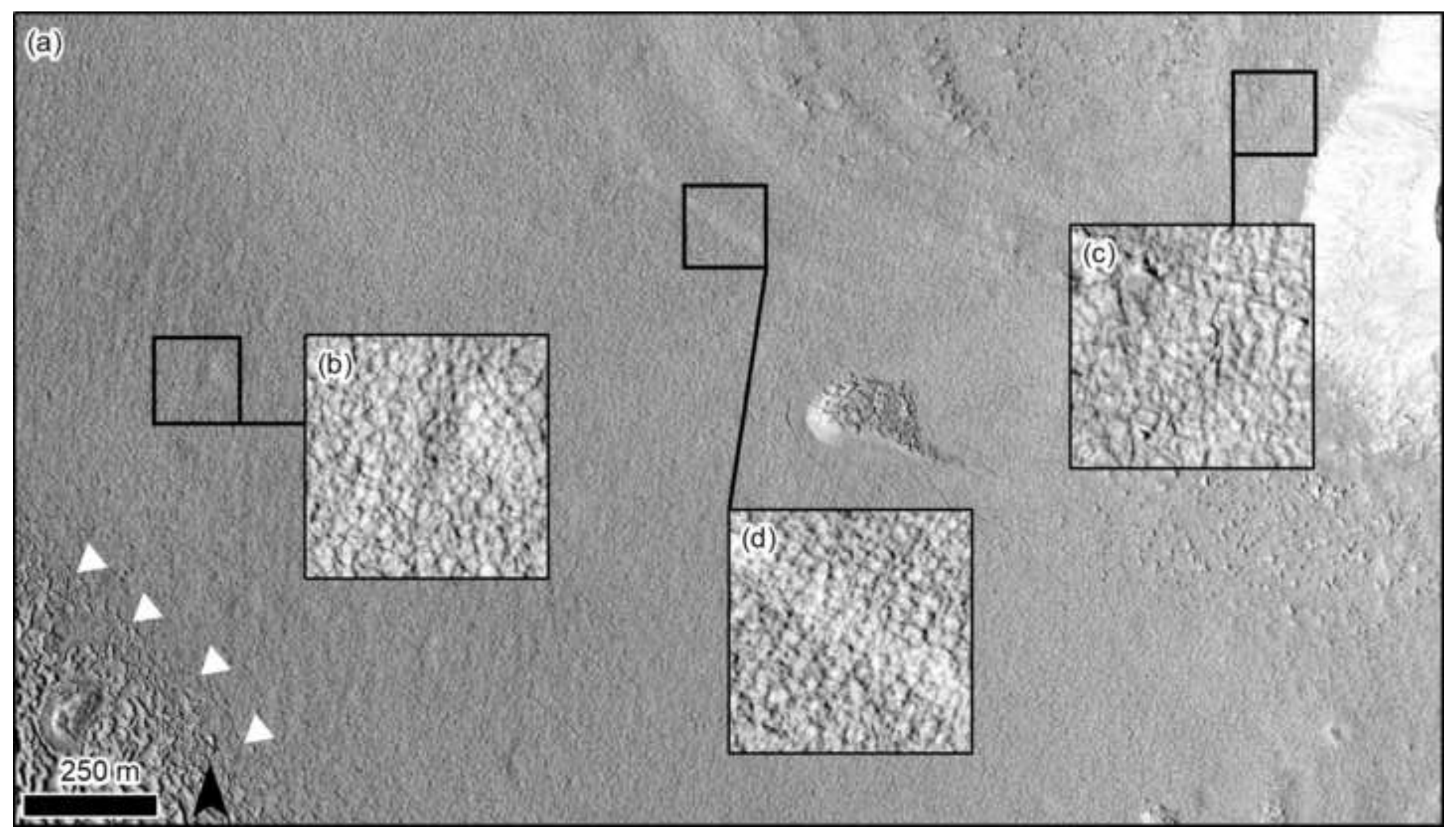




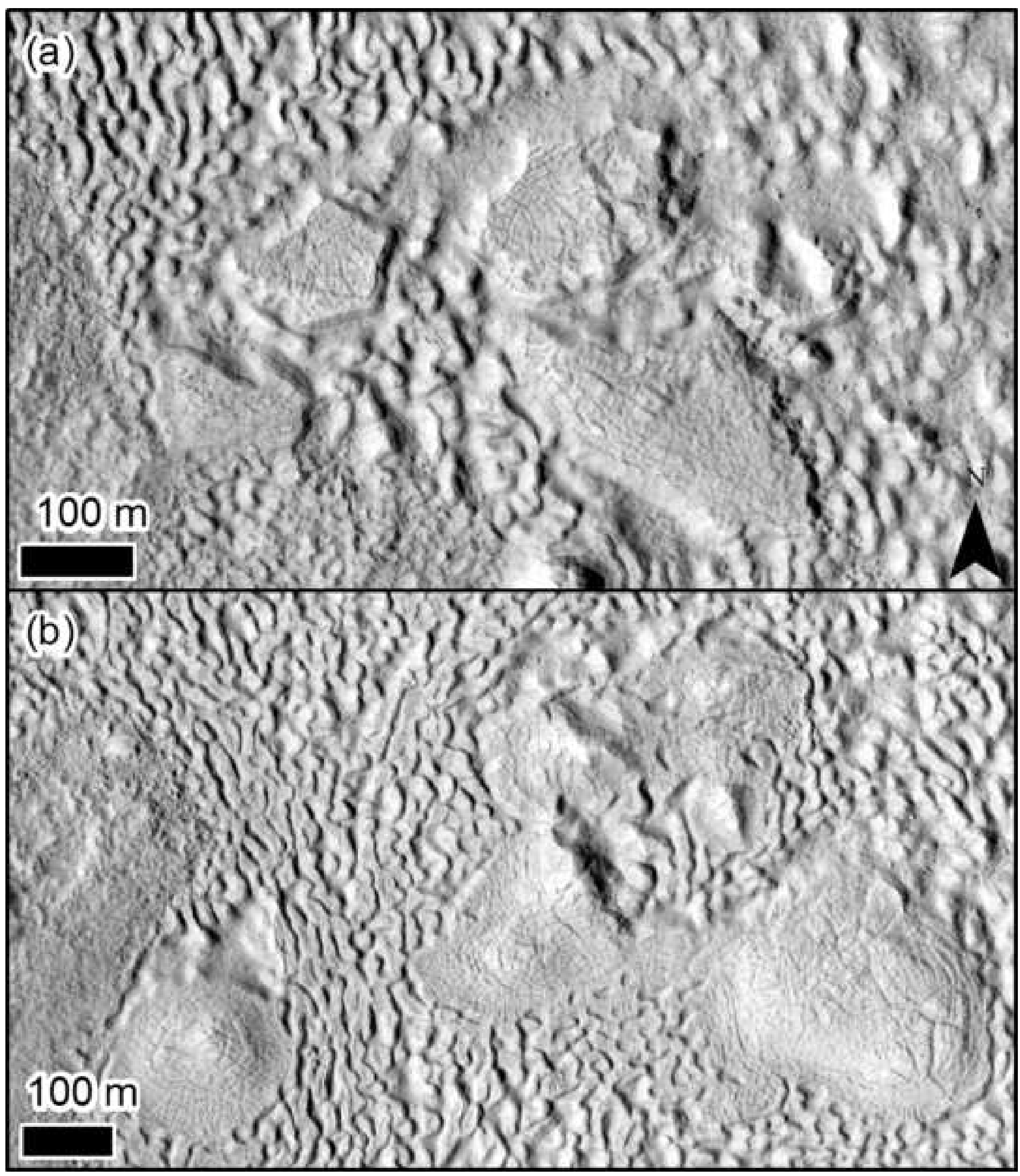




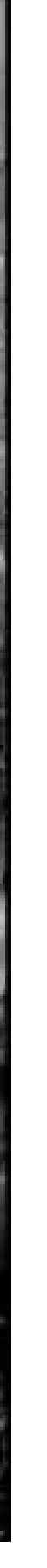

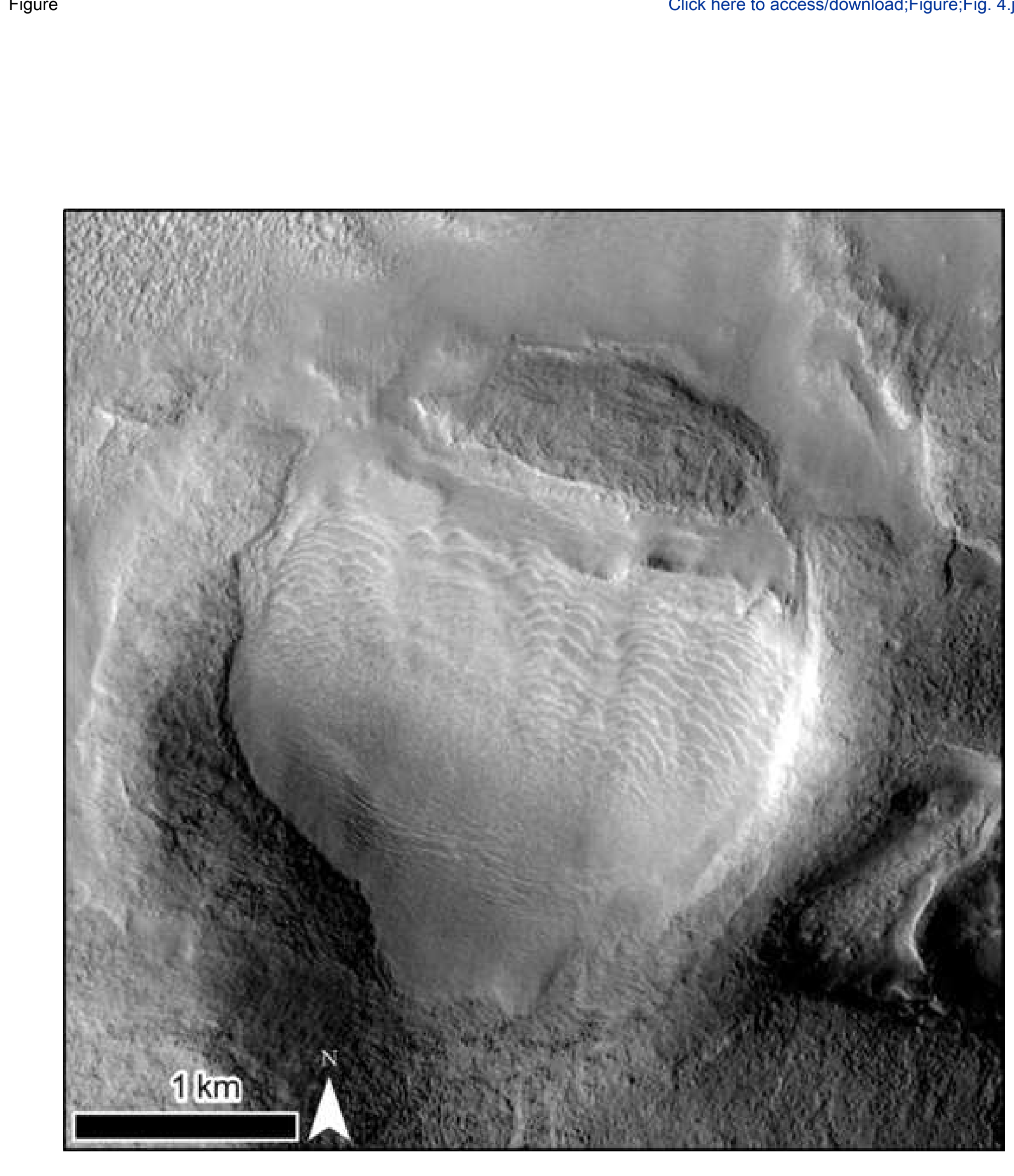

(

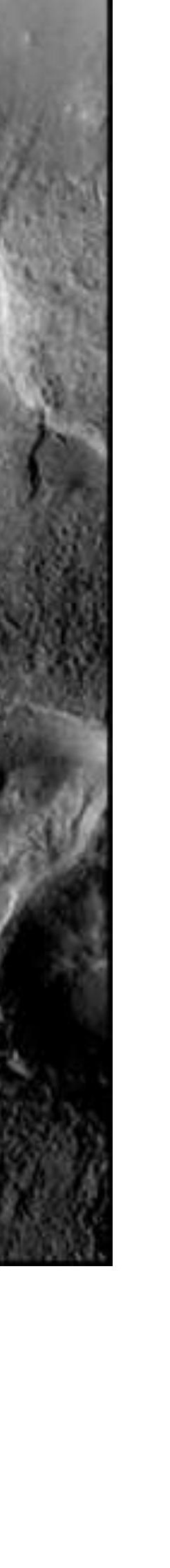

\section{.}




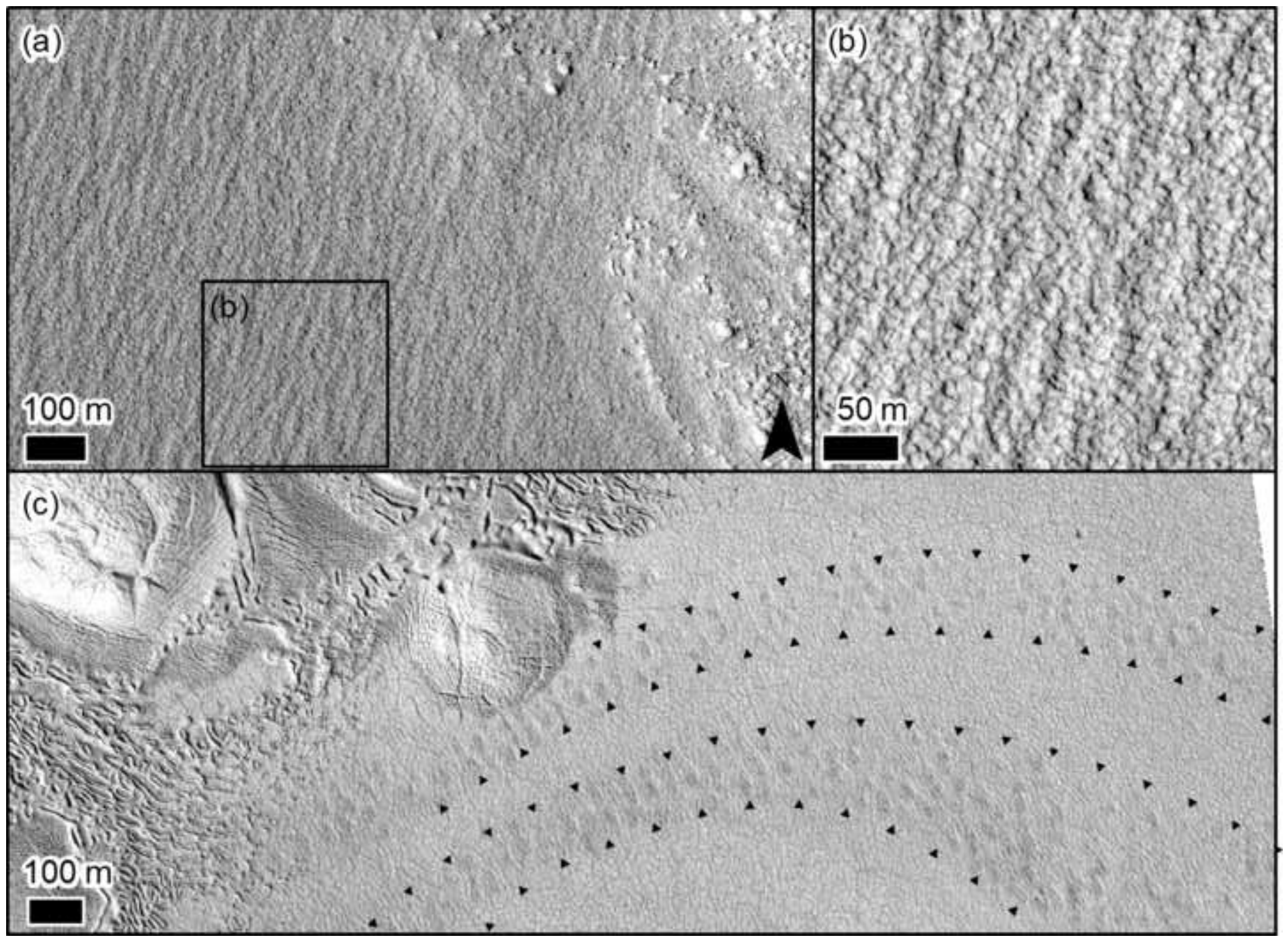




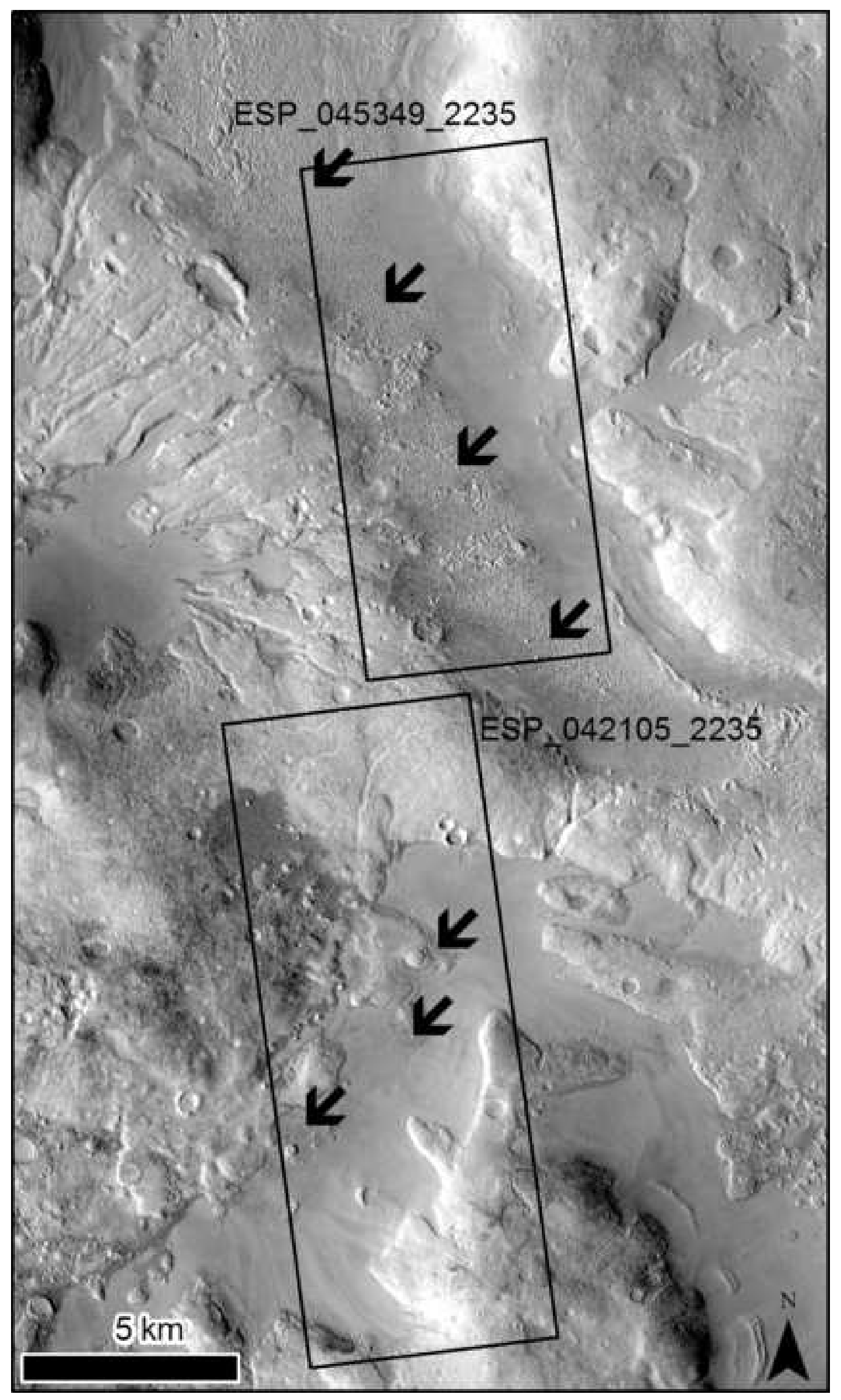




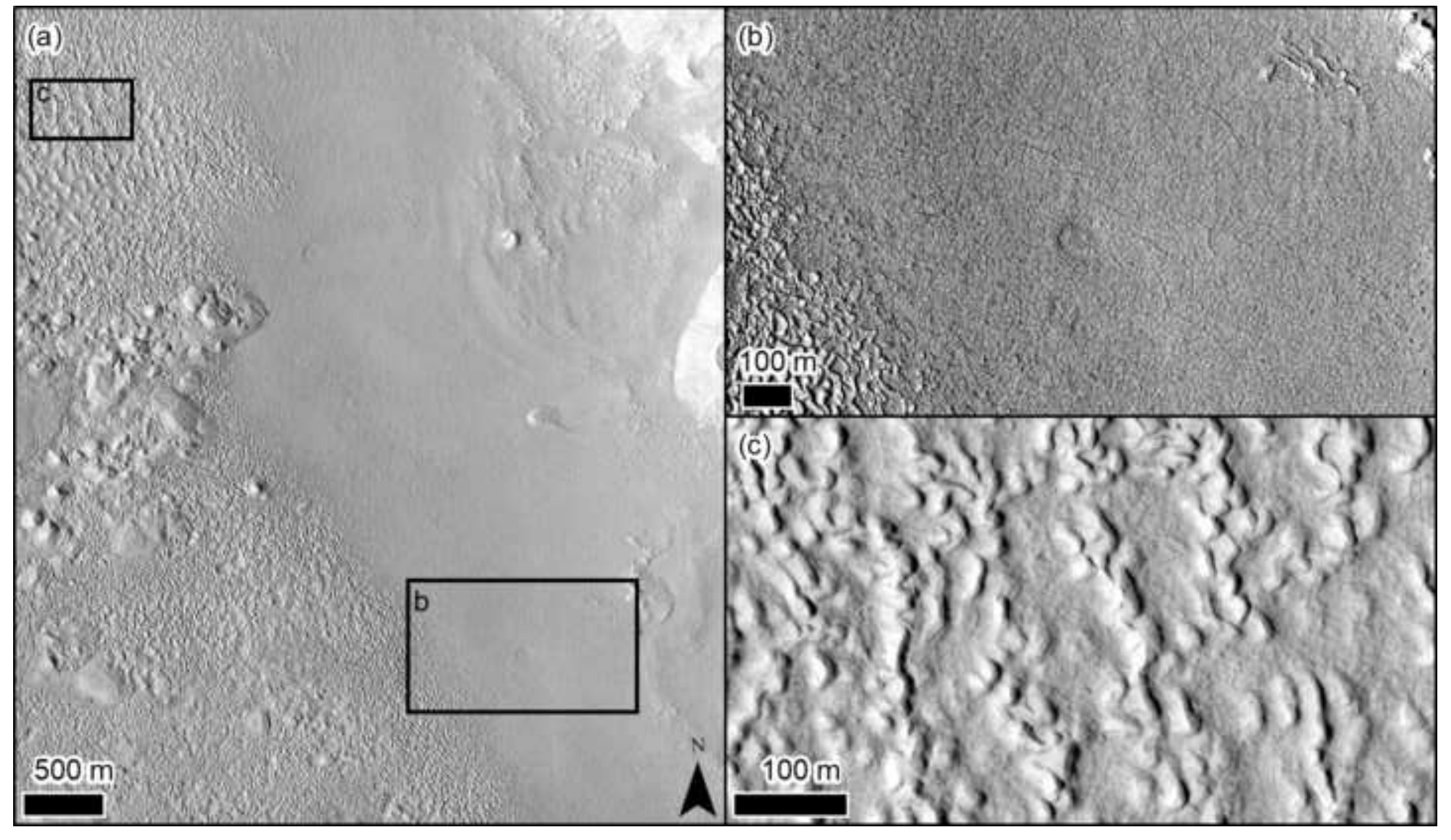




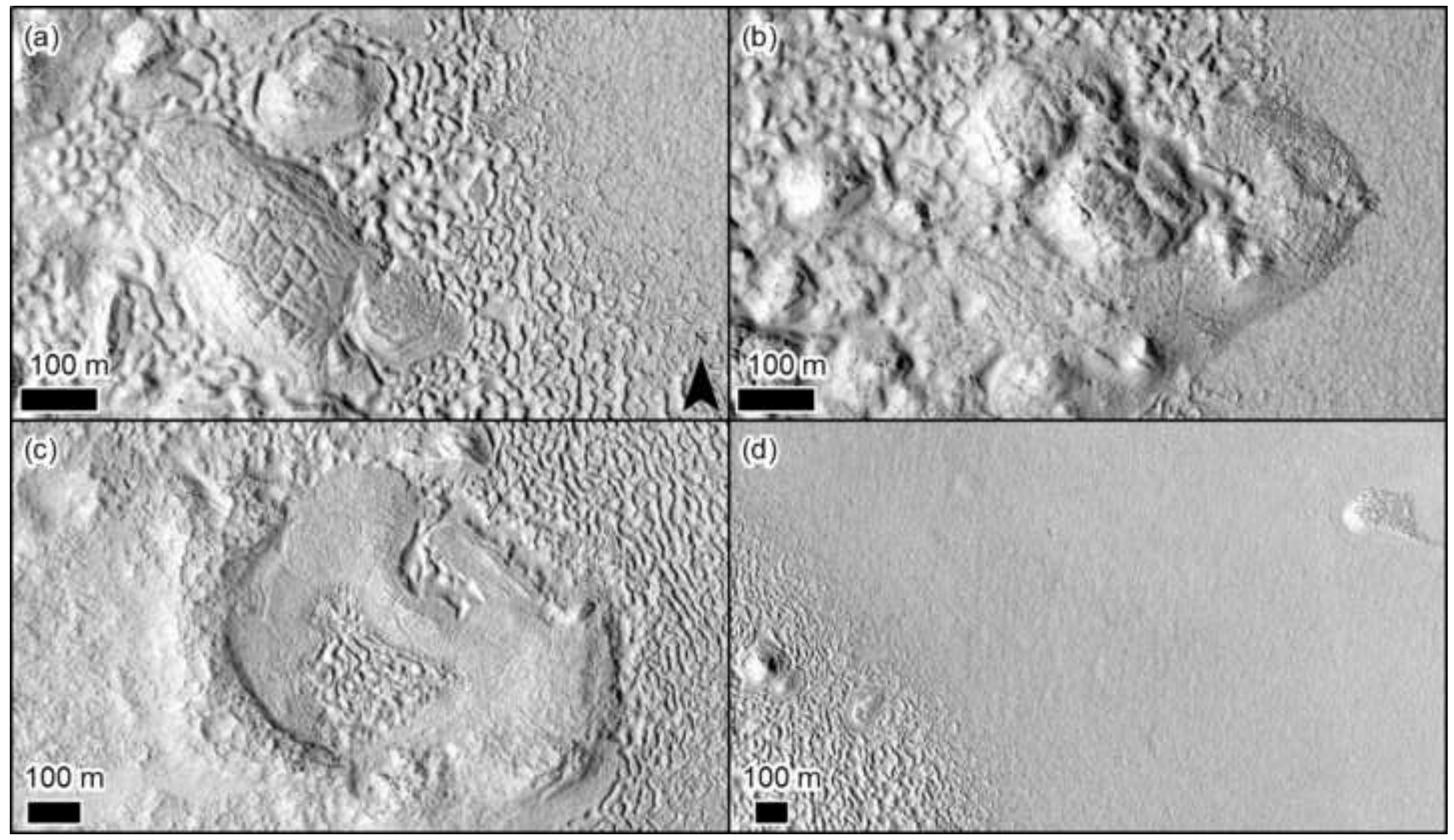




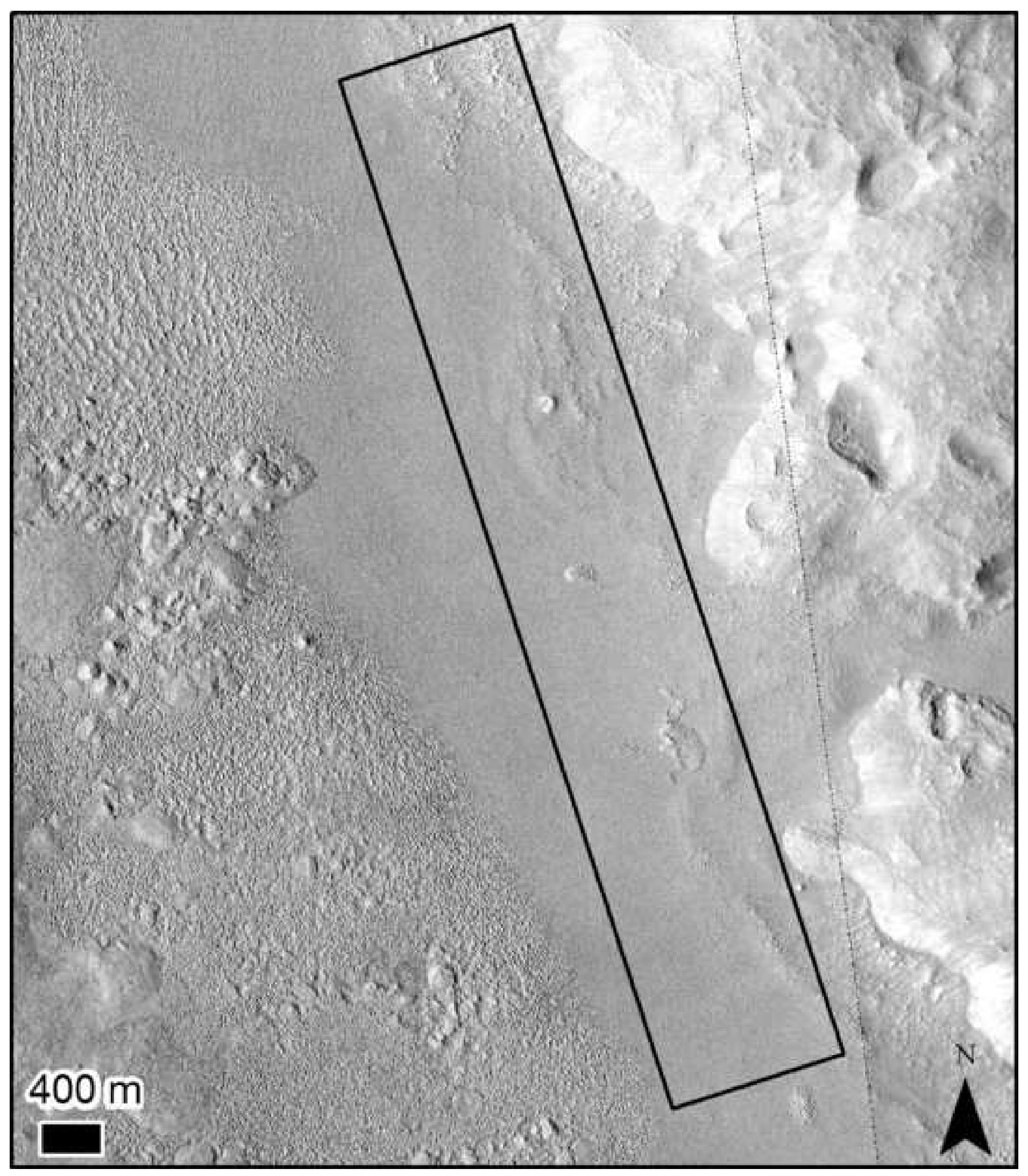




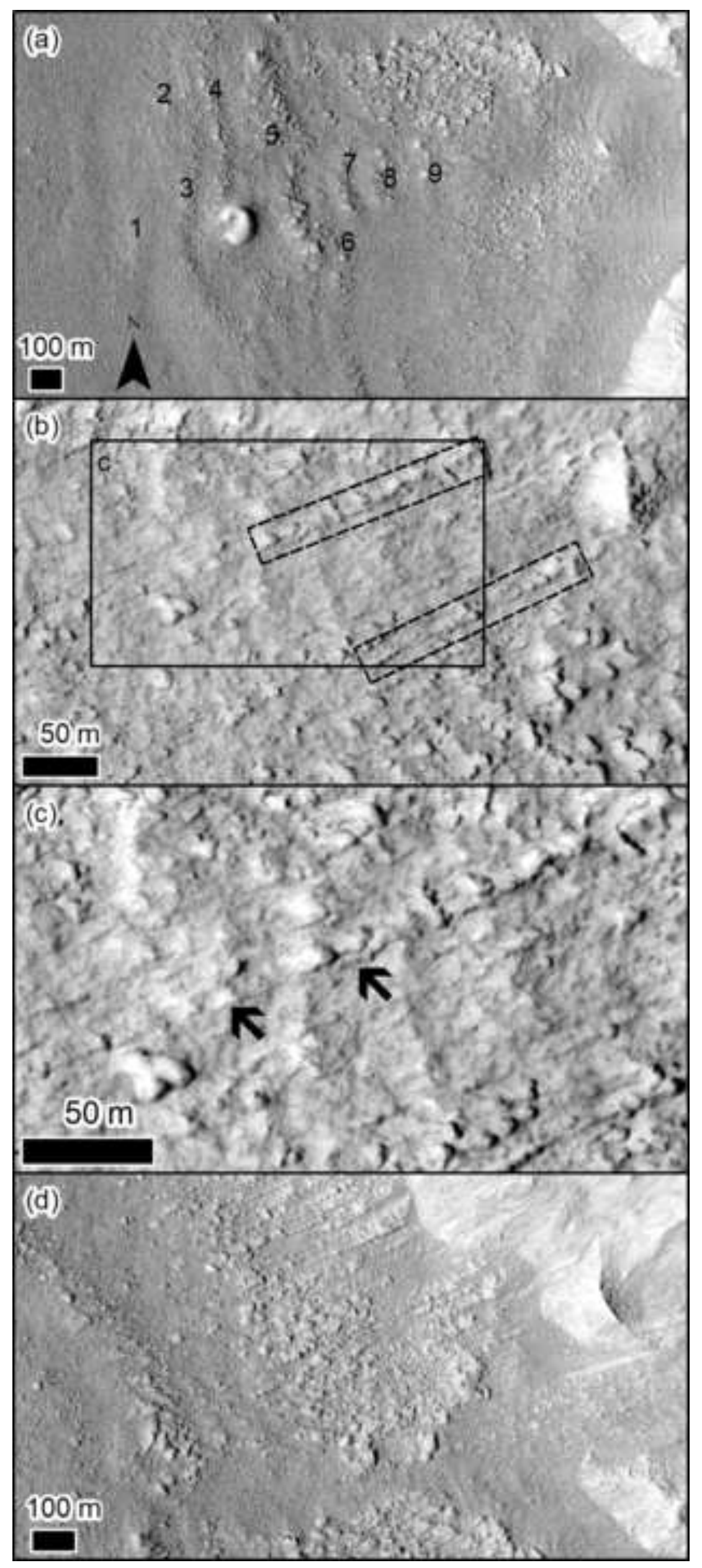




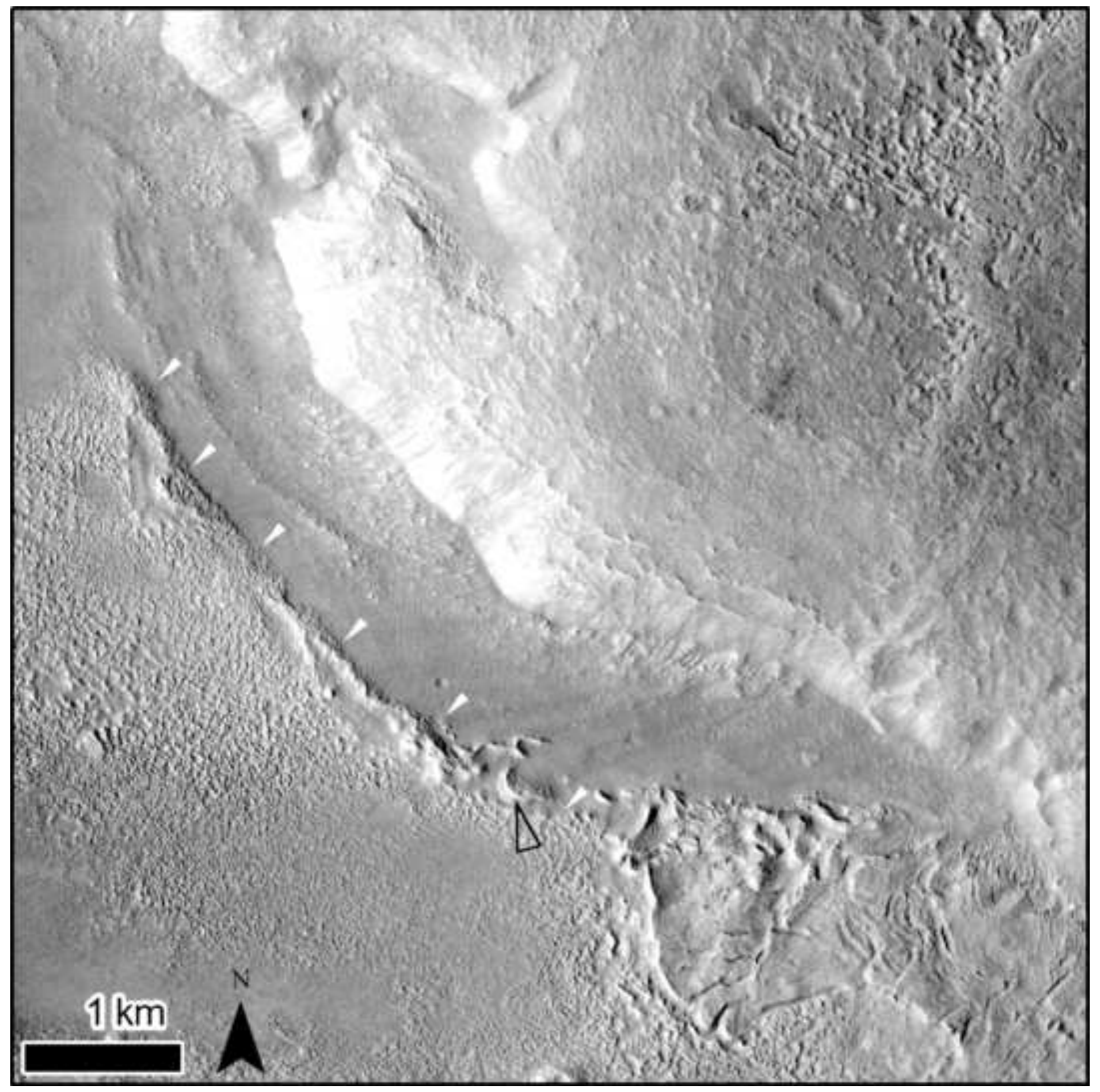




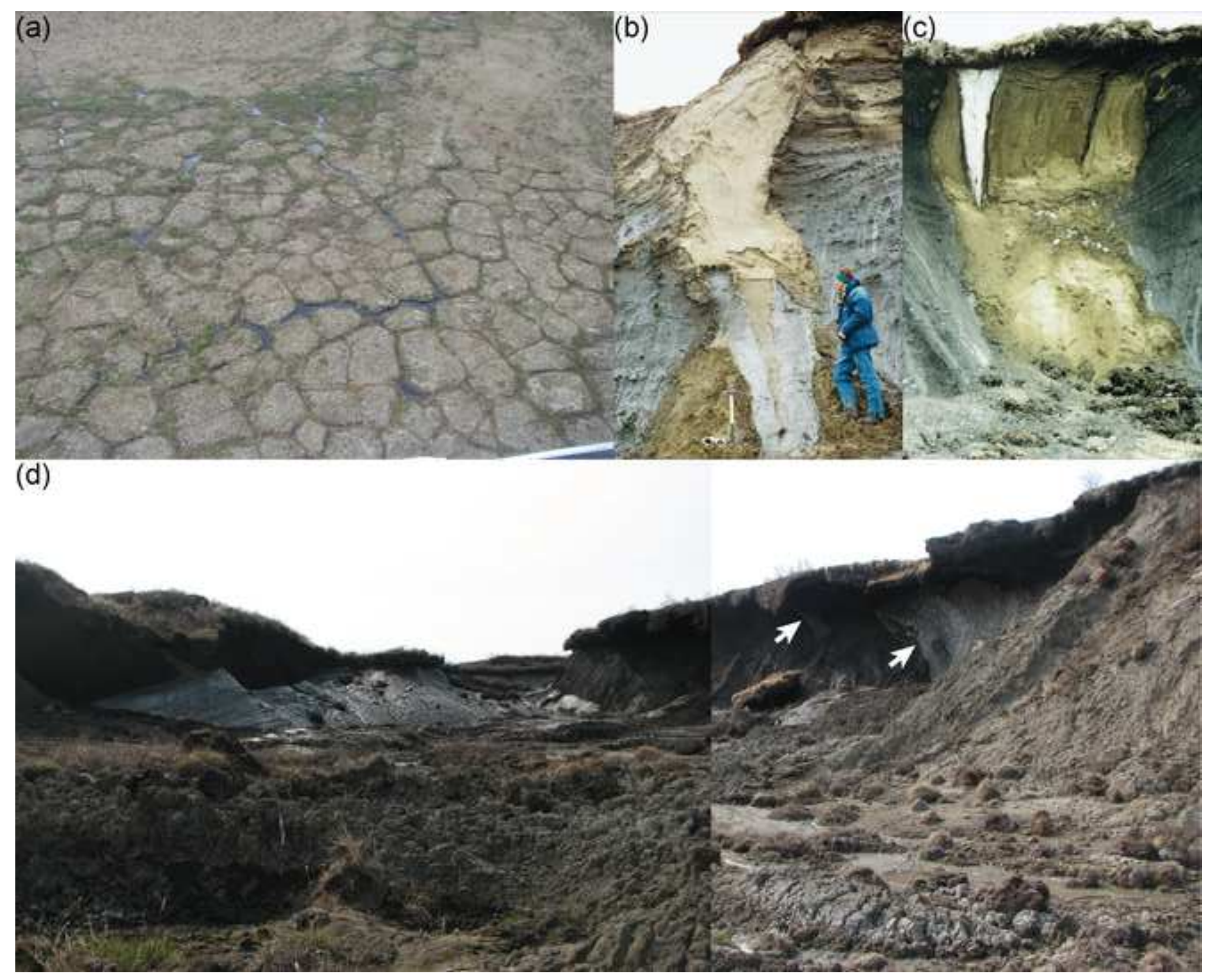

(b)

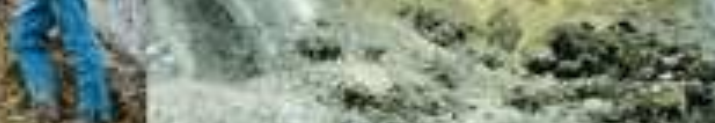

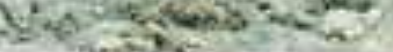

(d) 


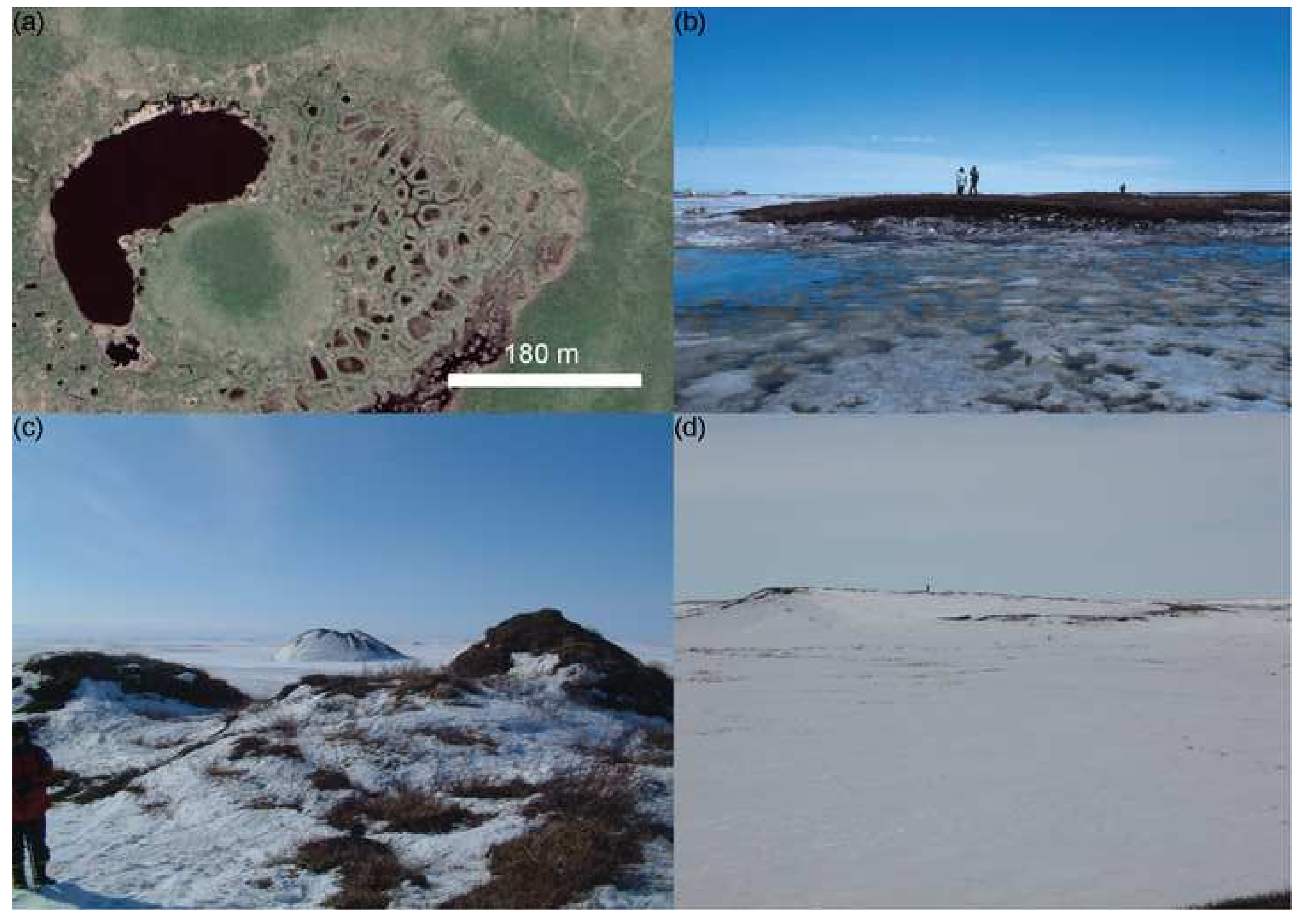



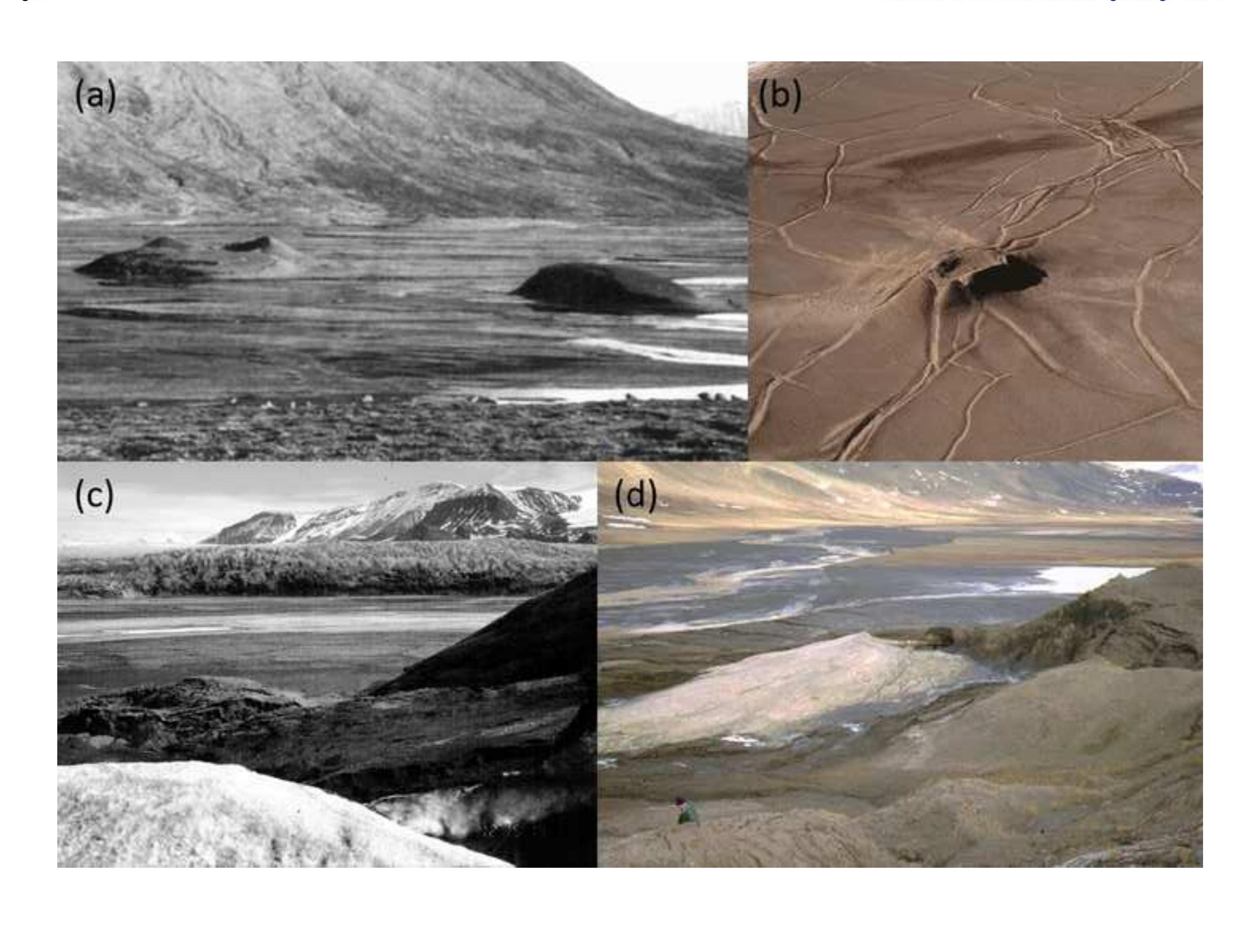

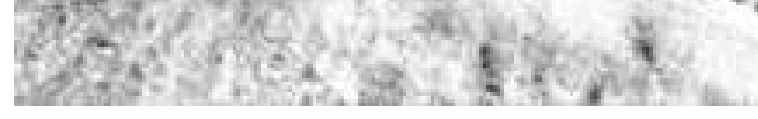

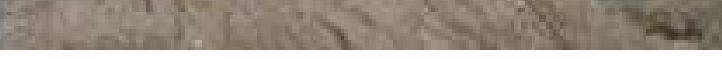

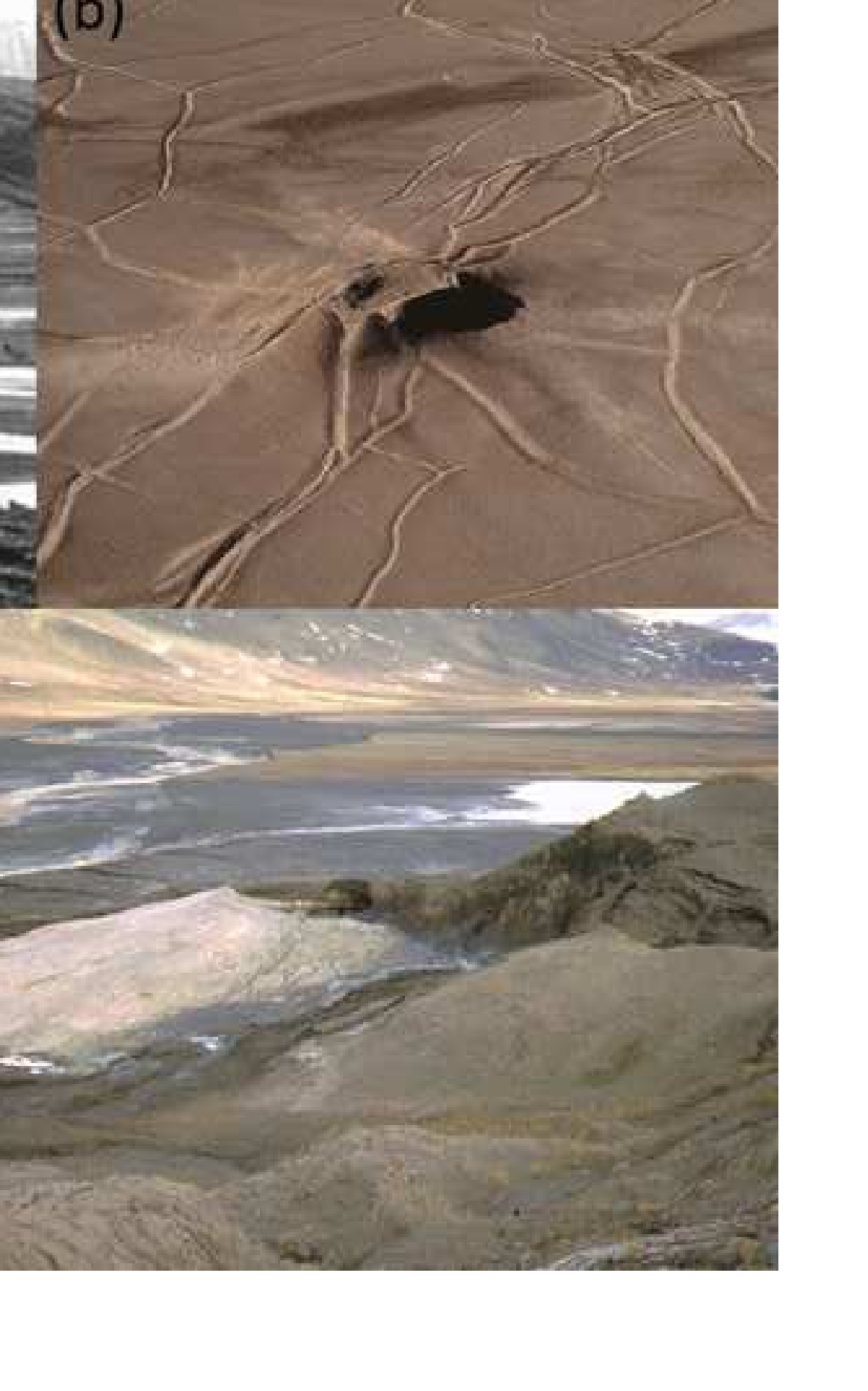



(1)

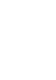

(c)

)

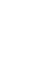

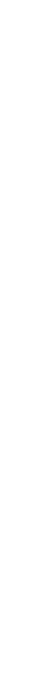




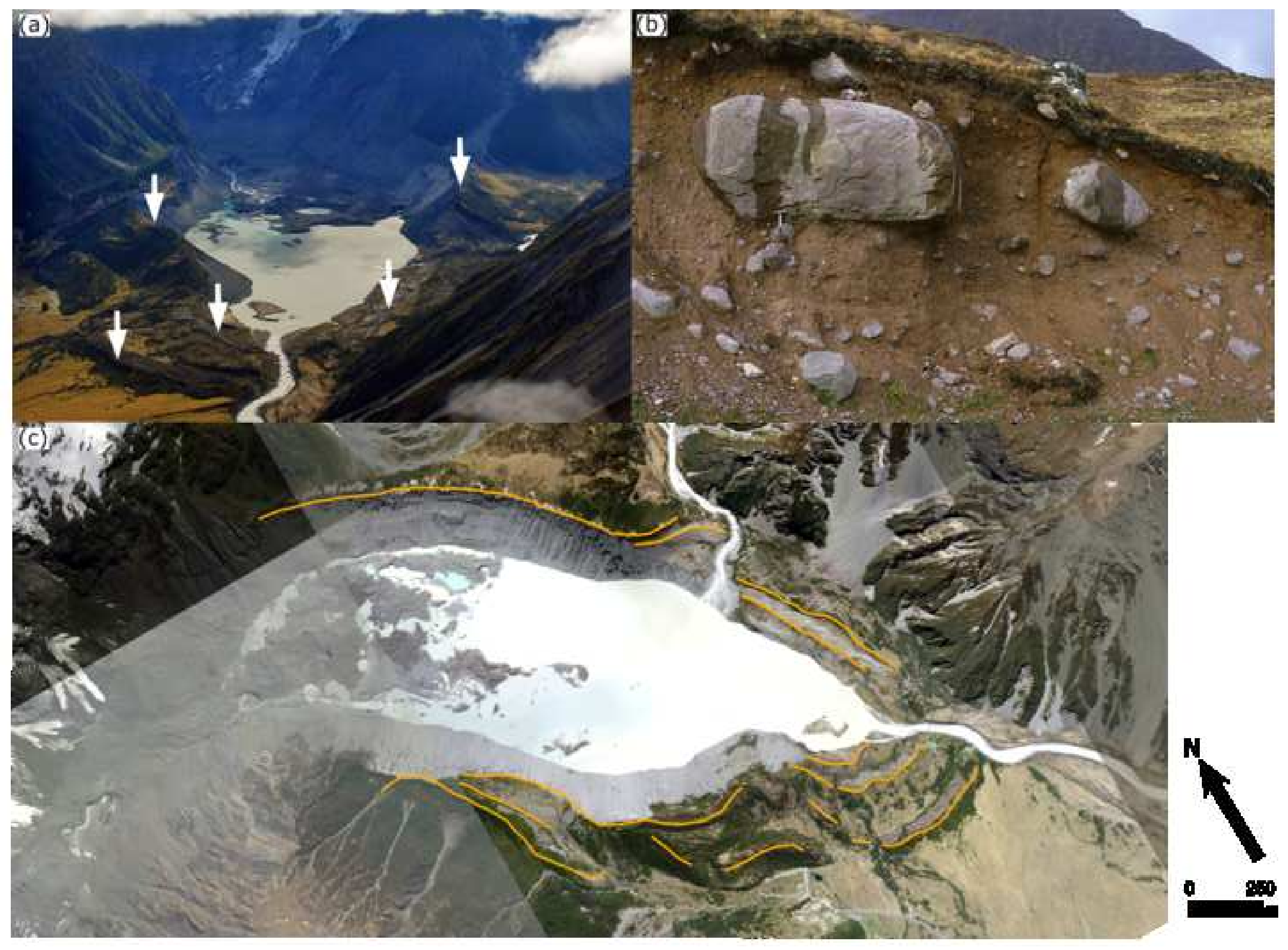




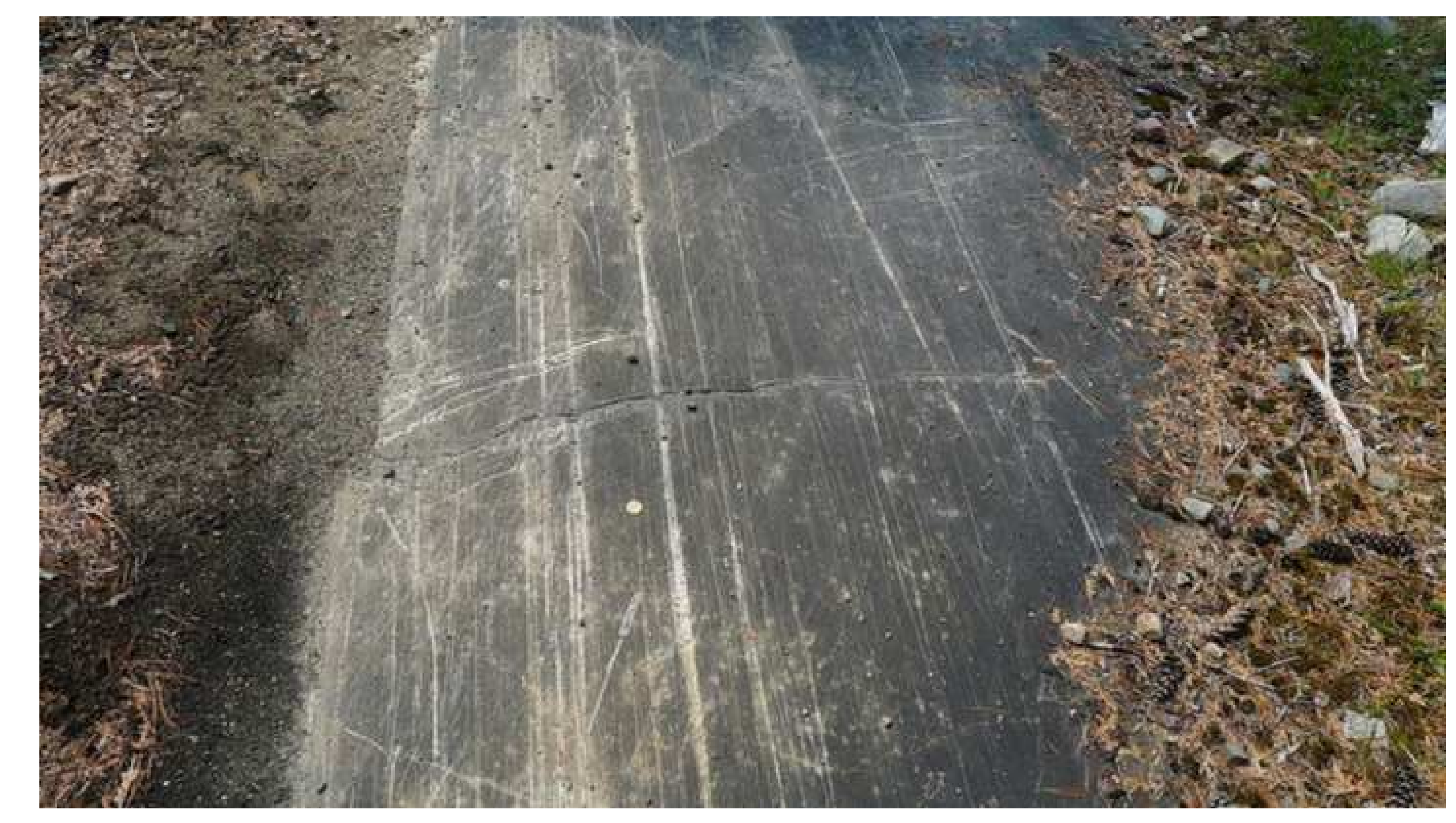




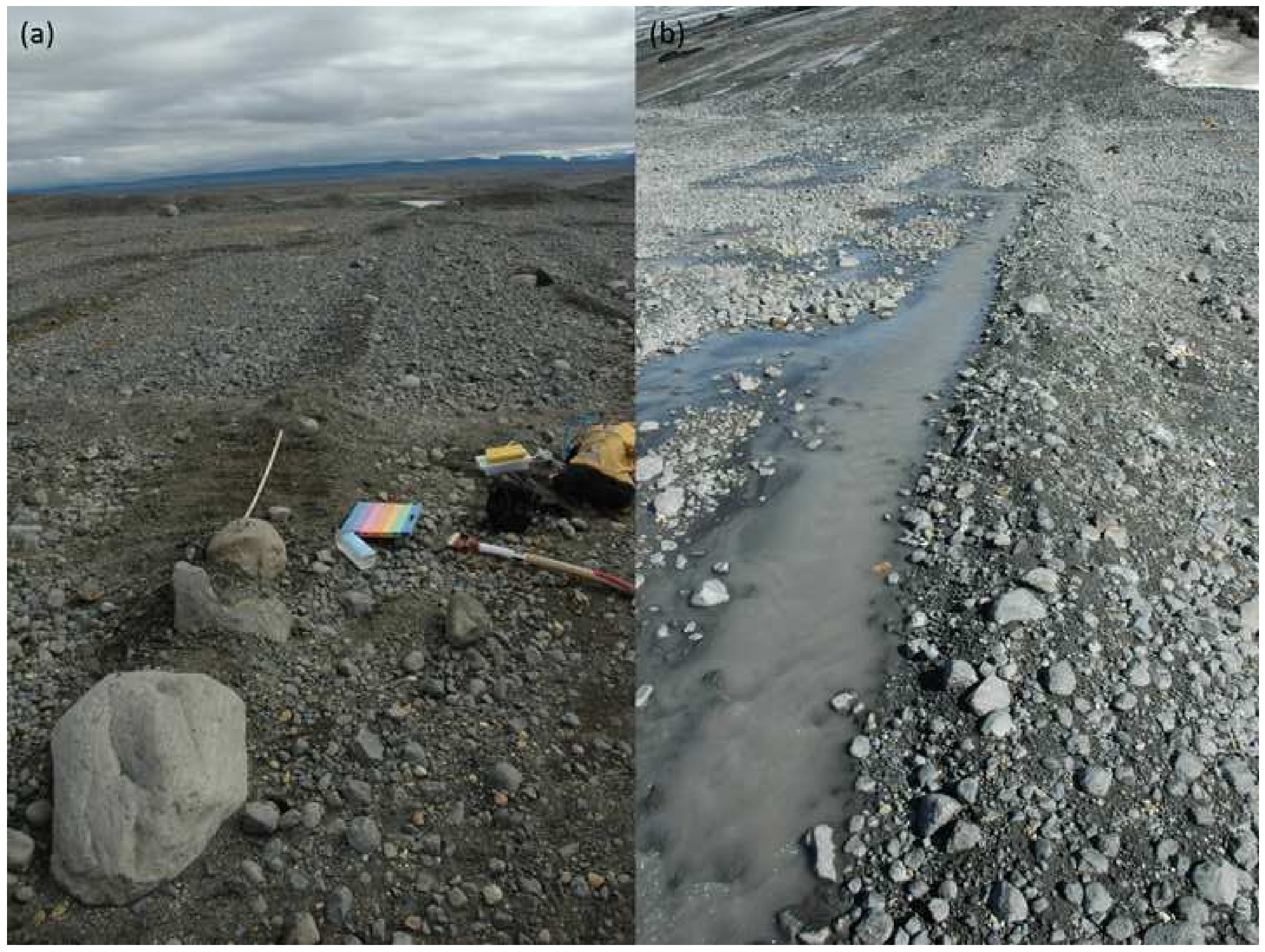




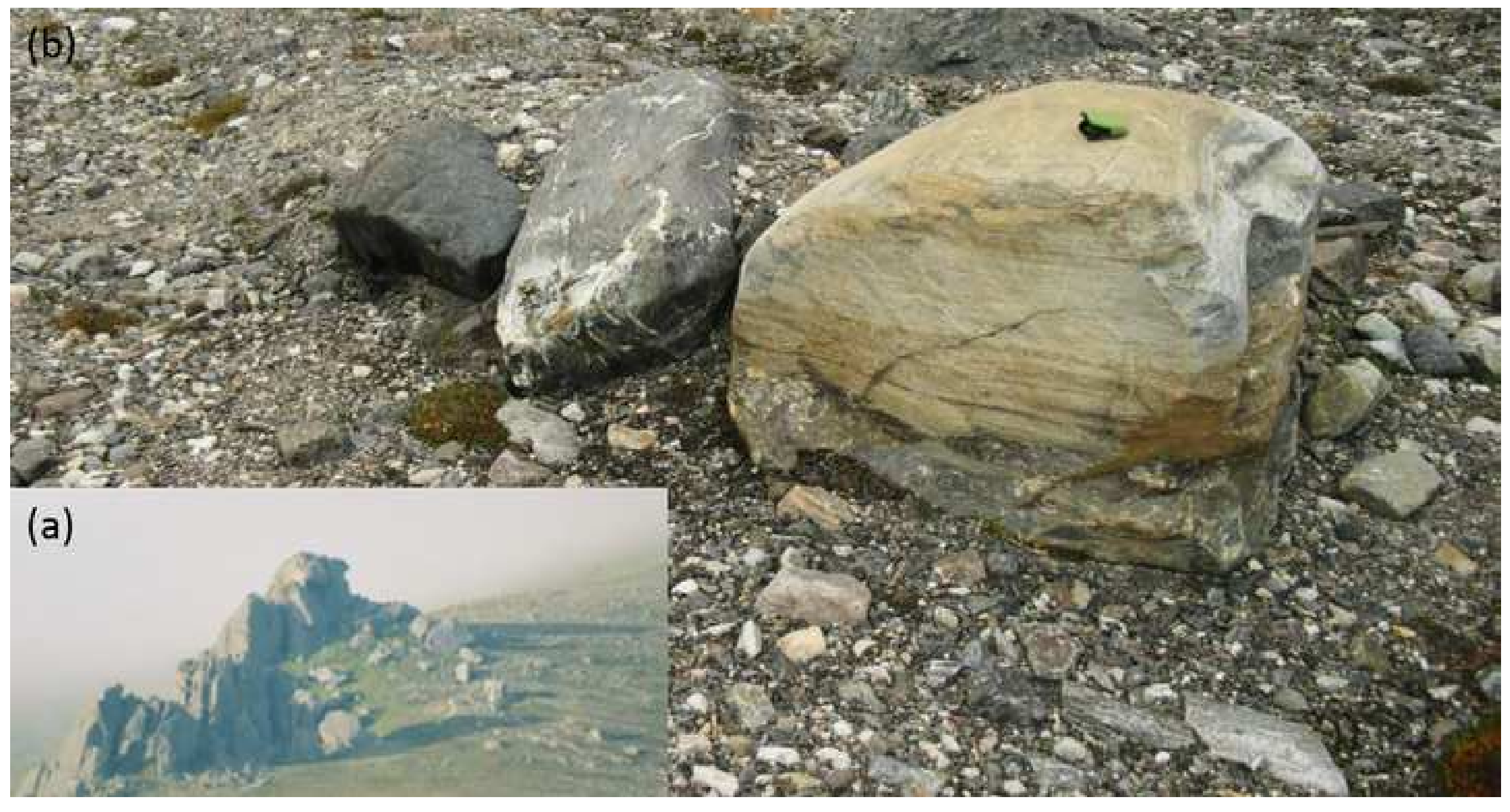




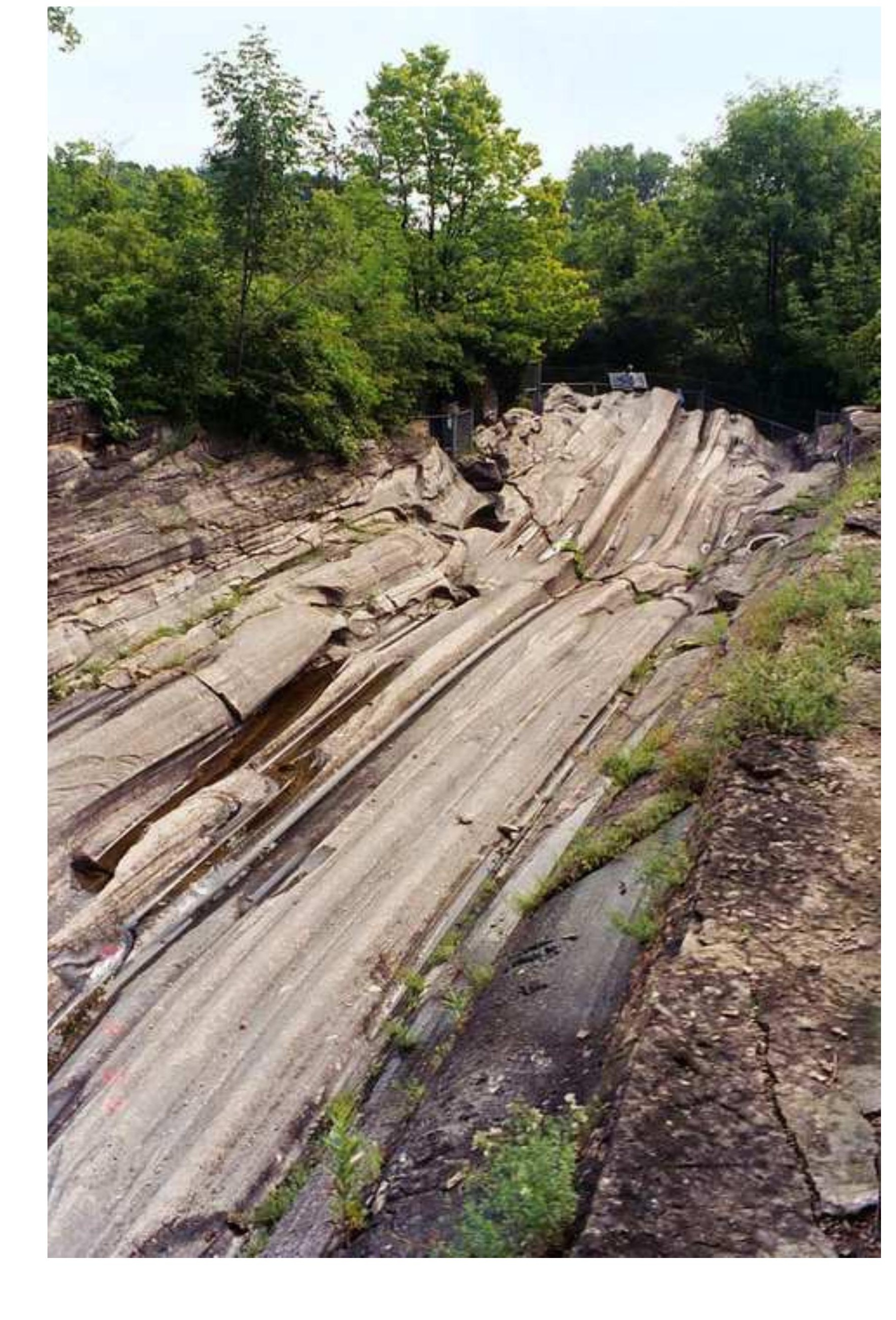

为

Figure $\quad$ Click here to access/download;Figure;Fig. 19.tif \pm$$
\text { ( }
$$ 
(a)

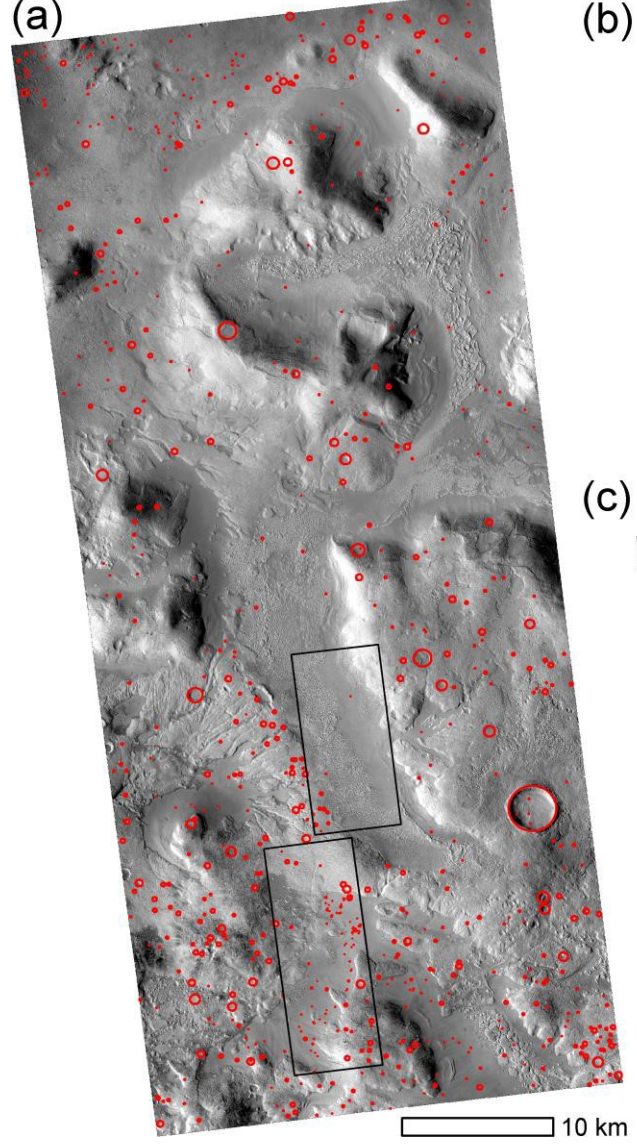

(b)

(c)

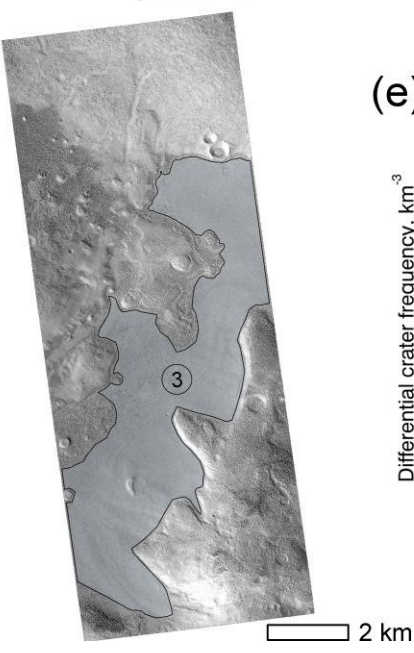

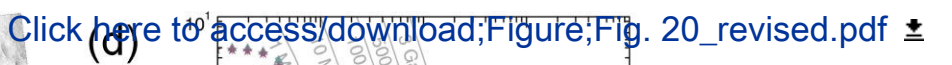

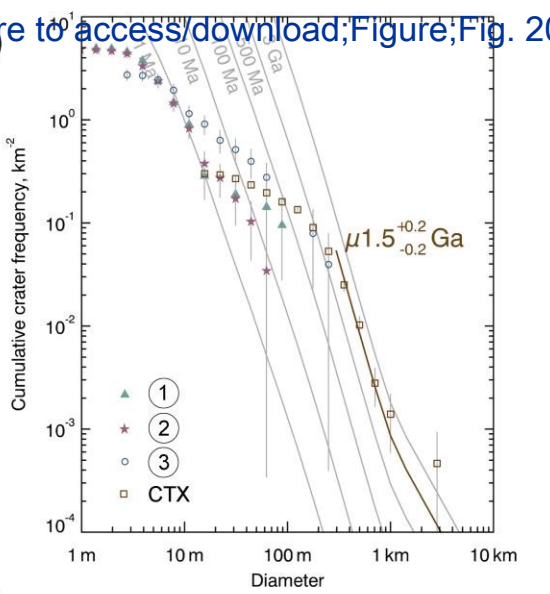

(e)

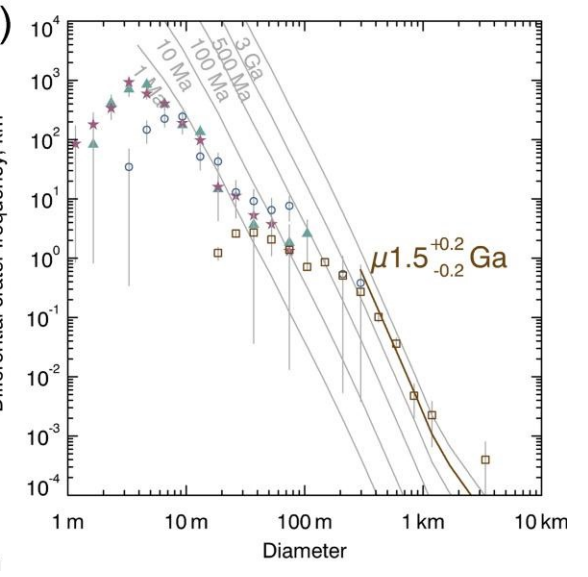



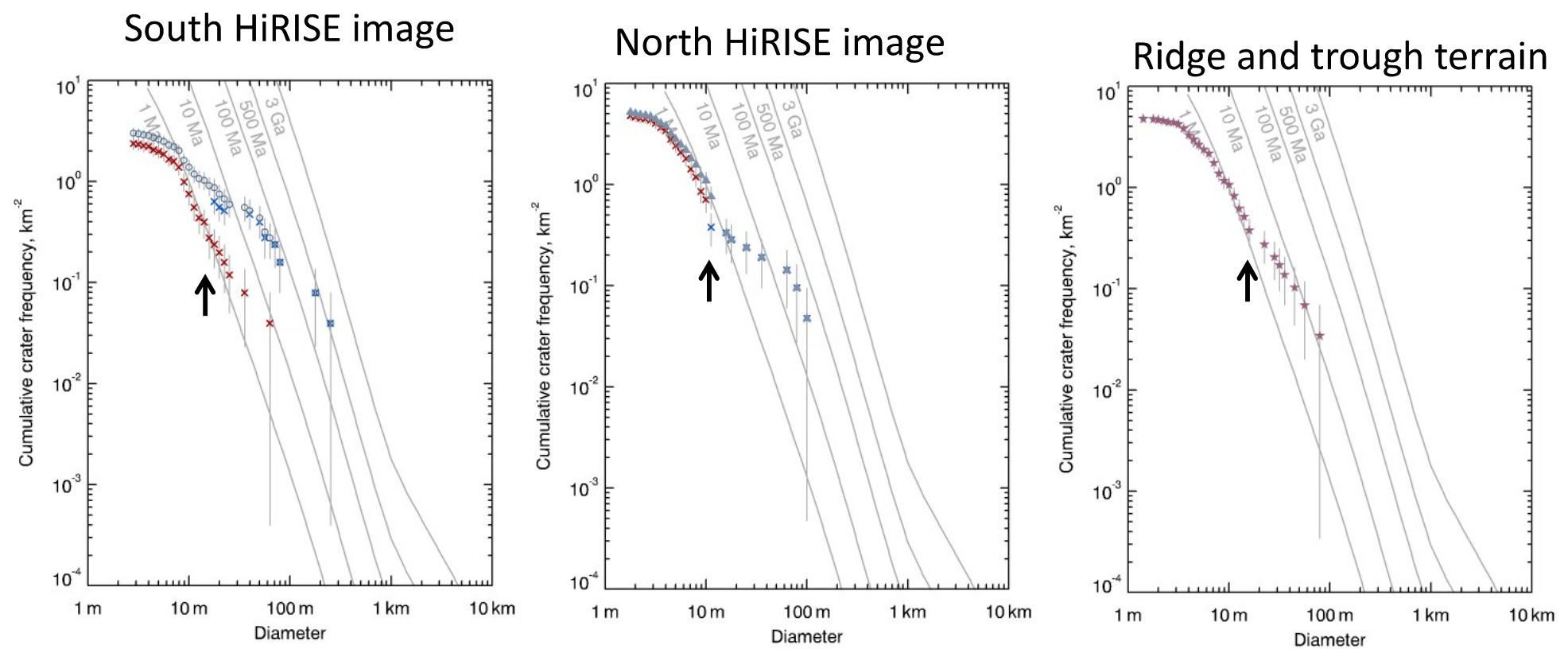

Blue ' $X$ ' are filled/polygonized craters

Red ' $X$ ' are bowl shaped craters 